\title{
The Effect of Social Programs and Exposure to Professionals on the Educational Aspirations of the Poor
}

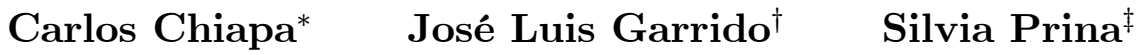

December 3, 2010

\begin{abstract}
Investment in human capital is an important tool for reducing poverty. However, the poor may lack the capacity to aspire, which often results in underinvestment in their children's education. This paper studies the effect of a social program on the educational aspirations of the poor, and explores the role of exposure to educated professionals as a possible channel for increasing aspirations. First, using differences-in-differences, we show that beneficiary parents of the Mexican antipoverty program PROGRESA have higher educational aspirations for their children of a third of a school year than do non-beneficiary parents. This effect corresponds to a $15 \%$ increase in the proportion of parents who aspire for their children to finish college. Then, we exploit the design of the program whose requirements cause its target population to have different levels of mandated exposure to doctors and nurses. Our triple difference estimate shows that, educational aspirations for children from high-exposure households (relative to lowexposure households) in treatment villages (relative to control villages) were a third of a school year higher six months after the start of the program (relative to before its introduction). These results suggest that the change in aspirations is driven by exposure to highly educated professionals.
\end{abstract}

\footnotetext{
${ }^{*}$ Centro de Estudios Económicos, El Colegio de México. Email: cchiapa@colmex.mx

${ }^{\dagger}$ Centro de Estudios Económicos, El Colegio de México. Email: jgarrido@colmex.mx

${ }^{\ddagger}$ Department of Economics, Case Western Reserve University. Email: silvia.prina@case.edu
} 


\section{Introduction}

Many have argued that education specifically and investment in human capital more generally could be the most effective way to reduce poverty (e.g., Becker, 1995). However, poverty may not only create constraints that limit the ability to invest in human capital, but it may also affect people's attitudes and interest in education. If the poor perceive a narrower range of life options or possibilities, they may lack the capacity to aspire, which leads to underinvestment in their children's education (Ray, 2006; Appadurai, 2004).

Research shows that parents' educational aspirations for their children are positively correlated with their children's educational outcomes (Goodman and Gregg, 2010; Gregg and Washbrook, 2009; and Gutman and Akerman, 2008a and 2008b), and that higher aspirations of the poor can lead to an increase in investment in human capital (Macours and Vakis, 2009). Hence, helping the poor to enhance their aspirations may have a positive effect on reducing poverty. In particular, understanding whether aspirations can be changed and identifying the channels through which this change can occur are essential. Unfortunately, little research is available on the evolution of aspirations.

This paper studies the effect of an antipoverty program on poor parents' educational aspirations for their children and explores the role of mandated exposure to educated professionals as a possible way to increase aspirations. In particular, it analyzes whether poor parents' aspirations for the educational attainment of their children can be improved as a result of exposure to doctors and nurses - a group of individuals with much higher educational level and economic status than theirs.

First, using differences-in-differences, we compare the outcomes of households that had been randomly selected to receive the benefits of the Mexican antipoverty program PROGRESA against the outcomes of households that had not been selected to participate in the program. Results suggest that beneficiary parents have higher educational aspirations for their children of a third of a school year than do non-beneficiary parents. When considering daughters and sons separately, we find a significant effect for daughters whereas there seems to be no significant effect for sons. The magnitude of this effect is comparable to that associated with parents having two extra years of schooling. This is quite relevant, given that the average education of adults in our sample is about three years. 
Furthermore, we consider as an alternative aspiration variable the proportion of parents who declared that they wanted their children to at least finish college in order to see the impact of the program on the proportion of households that aspired for their children to complete college. We find a $15 \%$ and a $19 \%$ increase in the proportion of parents who aspire for their children to complete college six months and one year after the start of the program, respectively. When considering daughters separately, increments are higher, with a $20 \%$ and a $25 \%$ increase in the proportion of parents who aspire for their daughters to complete college six months and one year after the start of the program, respectively. These findings add to the extensive literature on the direct and indirect effects of PROGRESA on a large number of outcomes. ${ }^{1}$

Next, we explore one possible channel through which PROGRESA might affect aspirations: exposure to educated professionals. We exploit the design of the program whose requirements cause its target population to have different levels of mandated exposure to doctors and nurses. We divide the sample into two groups: households with children less than five years of age - which have a high level of exposure to health personnel because they must visit the clinic at least four times per year-and households with no children less than five years of age - which have a low level of exposure to health personnel because they must visit the clinic only once or twice per year. To identify the effect of the differential exposure to educated professionals on parents' aspirations, we use a triple differences estimator. That is, we estimate the change in average aspirations before and after the introduction of PROGRESA for households with high exposure to highly educated professionals relative to households with low exposure in treatment villages relative to control villages. Average aspirations for children from high-exposure households (relative to low-exposure households) in treatment villages (relative to control villages) are a third of a school year higher six months after the start of the program (relative to before its introduction). This difference is statistically significant and suggests that the channel through which parental aspirations are changing is the households' exposure to highly educated professionals. When considering daughters and sons separately, we find a half of a school year effect for daughters and no statistically significant effect for sons. Moreover, exposure seems to trigger a $40 \%$

\footnotetext{
${ }^{1}$ For an excellent review of a number of studies that analyze the impact of PROGRESA, see Parker, Rubalcava, and Teruel (2008).
} 
increase in the proportion of high exposure parents who aspire for their daughters to finish college. We find no statistically significant effect for sons. A plausible explanation of why parents are changing their aspirations mainly for daughters and not for sons is that program participants are exposed to health professionals which are mainly female.

Interestingly, a year after the start of the program, the aspirations of parents from low-exposure households catch up with those of parents from high-exposure households. Recall that the low-exposure households are also required to visit the clinics, but with lesser frequency. Therefore, a good fraction might not have had exposure at the six-month time point. This suggests that aspirations might be affected by a minimum amount of exposure (i.e., a minimum number of meetings) and not by the frequency of exposure.

Some might worry that the interpretation of these results might not come solely from an exposure effect. However, we are able to rule out a number of alternative effects. These changes in aspirations are not due to an income effect from the cash transfers received by the households because transfers are higher for low-exposure households than for highexposure households. This is so because low-exposure households have a greater number of school-age children who are eligible to receive the educational cash transfers of PROGRESA, which constitute the largest component of the program's transfers. Furthermore, parental aspirations about their children's education do not seem to be driven by an age effect. Because parents' educational aspirations for their children are less malleable with the child's increasing age, we might be picking up a greater mutability of aspirations for younger children as opposed to older children. We explore this potential phenomenon by looking at the effect of variability in the child's age on aspirations, and we do not find such an effect. An additional concern could be associated with the fact that visits to the clinic might not only expose parents to educated professionals, but might also make children healthier and so have an impact on the educational aspirations of the parents. However, parental aspirations do not seem to be linked to children's health status. Moreover, the aspirations of non-eligible parents change neither at six months nor at one year after the start of PROGRESA, which indicates that our findings are not caused by any event occurring in the treatment villages that would have affected high-exposure households differently than low-exposure households. 
The finding that exposure to health professionals can contribute to changes in aspirations is important for at least three reasons. First, identifying a possible channel through which aspirations of the poor can be modified adds a new tool to the existing options that try to promote increased investments in human capital and productive assets as a means to escape poverty. Second, by design, a number of anti-poverty programs expose their target populations to doctors, nurses, teachers, and many other highly educated professionals. Policy-makers could harness the potential benefit of increased aspirations that are associated with exposure to highly educated professionals by encouraging or requiring that the beneficiaries of anti-poverty programs meet with such professionals a sufficient number of times. Third, the finding suggests that, in highly segregated environments or in contexts in which there is low social interaction or lack of leadership, promoting exposure to external educated professionals may have important consequences with respect to the aspirations of the population.

While the focus of this paper is on understanding the effect of exposure to professionals on aspirations, this effect might operate through a number of different mechanisms. Exposure to highly educated professionals may cause information flows that allow parents to learn about (previously unknown or previously considered unattainable) opportunities for their children and the investment it takes to reach these opportunities; it may change the consideration sets for people who have limited knowledge or bounded rationality; and/or it may change the socioeconomic environment of the poor.

This study is linked to the theoretical work on why exposure to individuals with a higher educational level and economic status may matter for increasing aspirations and decreasing poverty. In this sense, our paper brings support to the ideas developed in Ray (2006) and previously by anthropologists such as Appadurai (2004), which assign a central role in the formation and evolution of individual aspirations to the socioeconomic environment. ${ }^{2}$ This paper also relates to the active discussion on the fact that people's choices are affected by a limited considerations set. This basic idea has been discussed under a range of forms e.g., the literature on bounded rationality, narrowing bracketing, and limited attention (Rabin and Weizsäcker, forthcoming; DellaVigna, 2009; Barberis, Huang, and Thaler, 2006; Gabaix

\footnotetext{
${ }^{2}$ Additional papers are Mookherjee, Napel and Ray (2010), and Genicot and Ray (2009).
} 
et al., 2006; Kahneman, 2003; Rubinstein, 1998; Frank, 1985 and 1997; and Conlisk, 1996). Likewise, our research is connected to studies on how people's choices are conditioned by their sense of identity (Munshi and Rosenzweig, 2005; and Hoff and Pandey, 2004) and by their perceived returns (Jensen, 2010), as well as to the empirical literature on social interactions and peer effects, which shows that residents of poor neighborhoods achieve lower socioeconomic outcomes and attain lower educational levels than do the residents of more affluent neighborhoods (Gould, Lavy, and Paserman, 2009; Kling, Liebman, and Katz, 2007; Sánchez-Peña, 2007; and Case and Katz, 1991). In fact, our paper suggests that social exposure could be a way to attain better behavioral outcomes in poor areas.

The following section describes PROGRESA and explains how the program promotes the exposure of the beneficiaries to individuals with higher educational levels and economic status as well as how we identify the subgroups subject to a higher level of exposure. Section 3 describes the data. Section 4 outlines the empirical strategy and shows the results. Section 5 performs some robustness checks. Section 6 shows the relationship between educational aspirations and behavioral outcomes. Finally, Section 7 summarizes the results and concludes.

\section{PROGRESA and beneficiaries' exposure to health person- nel $^{3}$}

In 1997, the Mexican government started the Programa de Educación, Salud y Alimentación (PROGRESA) in rural Mexico in an effort to break the intergenerational transmission of poverty. The primary objective of the program is to improve the educational, health, and nutritional status of poor families, particularly of children and mothers (Skoufias, 2005). PROGRESA's two main components are health and education. In this paper, we exploit the key features of the former.

The health component of the program requires every female household head to attend her locality's health clinic to get educational talks about vaccinations, nutrition, contraception, and hygiene once a month. Furthermore, every family member must visit his or her

\footnotetext{
${ }^{3}$ This section draws extensively on Gertler (2000) and Skoufias (2005) who provide a much more detailed description of the program and evaluation data set.
} 
locality's health centers for preventive and/or monitoring check-ups for the household to qualify for the nutritional component. The frequency of the visits for each member depends on his or her age. Additionally, in the case of women, the frequency of the visits increases if the women are pregnant or have recently given birth. In particular, pregnant women must have five prenatal care visits starting in the first trimester; lactating women must have two visits a year during which their nutrition is monitored and they receive family-planning information and undergo physical check-ups; children less than two years old must visit the clinic every two months for growth monitoring, immunizations, and well-baby care; children 2-5 years old must visit the clinic every three months for growth monitoring, well-child care, and immunizations; children 5-16 must visit the clinic once every six months; and other adolescents and adults must visit the clinic for annual physical check-ups (Gertler, 2000; and PROGRESA, 1999). Qualified households secure a small monetary (health-conditional) transfer of a fixed amount regardless of household size. ${ }^{4}$ The main reason for which the program started providing health-conditional transfers was to stimulate health clinic attendance and regular check-ups, which were both very low in rural Mexico (see Gertler, 2000).

Hence, by fulfilling the requirements of the health component, PROGRESA's beneficiaries are exposed to nurses and doctors: i.e., individuals who have attained higher educational levels and higher economic status. In Mexico, in order to become a nurse it is necessary to earn a degree in nursing, which takes 2-5 years, after completing high school; to become a doctor, it is necessary to complete at least six years of a college degree in medicine. Thus, nurses have at least 14 years of education and doctors at least 18. These education levels are much higher than those of the adult population under consideration, which has, on average, three years of education (see Table 1).

The mandated exposure to doctors and nurses is more frequent for households with children less than five years old in particular compared to the frequency for households with older or no children at all. Households with children less than five years old must go to the health clinics at least four times per year. In contrast, households with older children

\footnotetext{
${ }^{4}$ Households also receive nutritional supplements for children less than two years old and pregnant and lactating women. Nutritional supplements are also provided for children ages 2-5 if they present stunting symptoms.
} 
must visit the health clinics twice per year, and households without children only once.

The other main component of the program is the educational component. Beneficiary households with children ages 9-17 who are enrolled in school and attending at least $85 \%$ of the school days each month as well as during the academic year receive an educationconditional grant. The grant increases with grade and, for secondary education, is slightly higher for girls than for boys. In addition, households with the appropriate school-age children receive a grant for school supplies. In general, all transfers are received by the female household head. ${ }^{5}$

On average, beneficiary households receive about 197 pesos monthly (expressed in November 1998 pesos) $;^{6}$ this represents $19.5 \%$ of the mean value of consumption of eligible households in control localities (Skoufias, 2005). The program has survived two changes of administration in Mexico. However, at its inception, beneficiaries were granted the program's benefits for only a three-year period. This was a credible threat because, prior to PROGRESA, social programs in Mexico used to dissolve as soon as there was a change in the political administration.

\section{The data}

An experimental design was adopted for PROGRESA's evaluation, exploiting its sequential expansion. A subset of 506 eligible localities in Guerrero, Hidalgo, Michoacán, Puebla, Querétaro, San Luis Potosí, and Veracruz was randomly chosen to participate in the evaluation sample: 320 localities were randomly chosen as treatment and started receiving benefits in May 1998; 186 were used as controls and started receiving benefits in December 1999. In the control localities, no household was informed that PROGRESA would have provided benefits at a later date.

In every locality where the program is implemented, households are selected as eligible to receive PROGRESA's benefits based on their poverty level. Data from the baseline survey shows that about $52 \%$ of the households in an eligible locality were classified as

\footnotetext{
${ }^{5}$ Children 13-17 years old in upper-secondary school can receive the transfers directly.

${ }^{6}$ The calculation of this average includes households that did not receive any benefits due to nonadherence to the conditions of the program or delays in the verification of the requirements of the program or in the delivery of the monetary benefits (Skoufias, 2005). The exchange rate at the time was about MX $\$ 10.00=$ US\$1.00.
} 
poor and were offered the opportunity to participate in the program. Only about $10 \%$ of these households chose not to enroll in PROGRESA. The data collected comprises repeated observations over eight survey rounds for 24,000 households.

The data used in this paper come from the first four survey rounds. ${ }^{7}$ The first two rounds were baseline surveys. That is, they were carried out before the program started giving benefits to the eligible treatment households. The last two rounds were carried out once PROGRESA had started giving benefits to the eligible treatment households but before control households were incorporated into the program. From these data-sets, we use only the observations of those households that were classified as poor at baseline unless otherwise noted. $^{8}$

The second, third, and fourth survey rounds contain data on aspirations. ${ }^{9}$ Specifically, the second baseline survey asks the following two questions to the person who responds to the questionnaire: "Up to what level would you like your daughters to study?" and "Up to what level would you like your sons to study?" 10 In the third and fourth rounds, the structure of the questions changed slightly. In these rounds, the respondent was asked to declare the highest level of education that she would like each of her daughters (sons) to complete.

Responses are coded by education level: elementary school (6 years of schooling), secondary school (9), high school (12), technical degree (12), college (16), and other (up to 21 if Ph.D.). For estimation purposes, we translated each of these levels into years of education as specified in the parentheses next to each level.

Because the second survey does not contain information about aspirations for each daughter (son) but for all daughters (sons) within a household, we conduct the analysis at the household level. ${ }^{11}$ Thus, for the third and fourth survey rounds, we compute the

\footnotetext{
${ }^{7}$ ENCASEH97, ENCEL98M, ENCEL98O, and ENCEL99M.

${ }^{8}$ By July 1999, the program's administration had added new households to the list of beneficiaries because it felt that the original selection method was biased against the elderly poor who no longer lived with their children (Skoufias, 2005). These households started receiving the benefits of PROGRESA about eight months after the original beneficiaries did (Skoufias, Davis, and de la Vega, 2001). For our analysis, we classify these households as non-elegible given their late admission.

${ }^{9}$ The first survey round does not include any question regarding aspirations, but contains important household and individual characteristics at baseline.

${ }^{10}$ The exact questions in Spanish are: ¿Hasta qué nivel le gustaría que estudiaran sus hijas? and ¿Hasta qué nivel le gustaría que estudiaran sus hijos?

${ }^{11}$ We also follow this strategy since the data-sets were designed to be matched from one round to the next at either the locality or household levels but not at the individual level. While from round to round
} 
maximum years of education that the respondent declared that she would like her daughters (sons) to study if the household has more than one daughter (son) in order to match this information with the responses from the second survey round. ${ }^{12}$ Finally, in order to analyze changes in parental aspirations for all children, we compute the maximum years of education that the respondent declared she would like any of her children to study. ${ }^{13}$

Behrman and Todd (1999) compare the characteristics of treatment and control group households as measured at a point in time prior to having received any program services to determine whether the control and treatment groups truly appear to have been randomly assigned. An examination of the characteristics of the groups in terms of age, education, access to health care, and income at the household level show more rejections of the null than would be expected by chance given standard significance levels. Behrman and Todd believe that these many rejections are due to the fact that the samples are large and tend to reject even for minor differences.

Table 1 shows descriptive statistics by treatment status of some relevant characteristics of the head of the household and the spouse of the head, such as their ages, educational levels, and whether they were literate or spoke an indigenous language at baseline. Table 1 also presents information on household characteristics and demographic structure. Treatment and control households do not seem to differ significantly except for the fact that treatment households appear to have a somewhat younger head and a slightly higher proportion of male children. In the empirical analysis, we control for such differences.

the demographic composition of the households does not present important changes, on average, trying to match individuals results in many incongruencies. Parker, Rubalcava, and Teruel (2008) acknowledge that some problems with matching identifiers at the individual level have been reported and refer the reader to Teruel and Rubalcava (2007) for further discussion.

${ }^{12}$ The fact that the aspiration question changed slightly between rounds may raise the concern that parents could change the answers they provide. For example, when asked the question as in the second survey round, a mother may say she would love all her children to be rocket scientists because she values education, but when asked about a specific child, as in survey rounds three and four, her aspirations may also reflect her expectations about the child's abilities, and she may say she would be happy if the child just finished high school. If this were to be the case, the variable computing the maximum number of years of education that the respondent declared that she would like her daughters (sons) to study would be different than the variable computing the minimum number of years of education that the respondent declared that she would like her daughters (sons) to study. However we do not find this. Also, the results of the paper do not change when using as alternative variable the minimum instead of the maximum.

${ }^{13}$ Results do not change if we use the minimun years of education. 


\section{Empirical strategy and results}

This section is divided into two parts. First, we study the effect of PROGRESA on the educational aspirations of the poor. Then, we investigate exposure to educated professionals as a possible channel through which aspirations might change.

\subsection{PROGRESA's effect on aspirations}

Having information on the parents' aspirations for their children's education from three periods (one before and two after the implementation of the program) allows us to estimate the impact after the first six months and after one year from the start of PROGRESA. Table 2 summarizes the levels and changes in parental aspirations for children dividing the sample into treatment and control groups. We present data for all children in columns (i)-(iii), for daughters in columns (iv)-(vi), and for sons in columns (vii)-(ix). The first two columns for either all children, daughters, or sons show the data by treatment category; the third column shows the differences in average parental aspirations between treatment and control households. Rows 1-3 of the table present the average parental aspirations in levels at baseline, six months, and one year after the start of PROGRESA, respectively. Rows 4 and 5 show the changes in average parental aspirations between baseline and six months and between baseline and one year, respectively.

Table 2 shows that, before PROGRESA started, parental aspirations were slightly lower in the treatment group than in the control group; however, these differences are not statistically significant. After the start of the program, the aspirations of parents in the treatment group increased relatively more than did the aspirations of parents in the control group. The relative increase (the "differences-in-differences" of the changes in parental aspirations) for all children is 0.31 and 0.27 years of schooling after six months and one year of the start of the program, respectively, 0.38 and 0.36 years of schooling for daughters, and 0.27 and 0.21 years of schooling for sons. These numbers are statistically significant when considering all children and daughters. Hence, PROGRESA seems to increase the educational aspirations parents have for their children, particularly their daughters, by about a third of a school year.

As shown in Table 1, both treatment and control groups are quite similar but differ with 
respect to the age of the head of the household and the proportion of male children. Thus, we incorporate these potential sources of variation in the parental educational aspirations in the estimates of the following reduced form regression:

$$
A S P_{i v t}=\alpha+\beta_{1} X_{i v t}+\beta_{2} \tau_{t}+\beta_{3} T_{v}+\beta_{4}\left(T_{v} \times \tau_{t}\right)+\varepsilon_{i v t}
$$

where $A S P_{i v t}$ denotes the educational aspirations of the parents of household $i$ in village $v$ at time $t ; X_{i v t}$ represents the set of observable characteristics that turned out to be statistically different between control and treatment households; ${ }^{14} \tau_{t}$ is a time dummy; $T_{v}$ is a village dummy that equals one for households in treatment villages; and $\varepsilon_{i v t}$ is an idiosyncratic error term. The coefficient of interest is $\beta_{4}$, which estimates the impact of PROGRESA on the educational aspirations of the beneficiaries towards their children.

The estimates of regression (1) are reported in Table 3. We analyze the impact of PROGRESA on the educational aspirations of parents towards all their children (columns 1-3), and towards their daughters (columns 4-6) and their sons (columns 7-9) separately. Panels $\mathrm{A}$ and $\mathrm{B}$ in Table 3 present the regression results six months and one year after the start of the program, respectively. We estimate this effect without controlling for unbalanced household characteristics in columns (1), (4), and (7), and including controls in columns (3), (6), and (9). In all specifications we cluster the standard errors at the village level. All estimates are very similar to the simple differences-in-differences results shown in Table 2. PROGRESA is associated with an increase in educational aspirations of a third of a school year. Including the control variables alters neither the magnitude nor the precision of the coefficient of interest in any of the regressions.

Finally, in columns (2), (5), and (8) we include the parents' highest educational level in years. The magnitude of the coefficients indicates that, ceteris paribus, PROGRESA's effect on aspirations for all children is comparable to that associated with parents having two extra years of schooling (considering column $(2): \frac{0.313}{0.165}=1.9$ ). When considering only daughters the effect is stronger (considering column $(5): \frac{0.382}{0.167}=2.3$ ). This is quite relevant, given that the average education of adults in our sample is about three years (as shown in

\footnotetext{
${ }^{14}$ The variables that are statistically different are the age of the head of the household and the proportion of male children in the household.
} 
Table 1). There seems to be no significant effect for sons.

In order to better understand the reason why changes in parental aspirations are greater for daughters than for sons, it would be useful to have data on the gender of the personnel in the health clinics in the 1998-1999 period. Unfortunately, this type of data is available for 2007 only. In this year, while $46 \%$ of the doctors were female doctors, $93 \%$ of the nurses were female nurses. Thus, to the extent that the proportion of female doctors and nurses in 1998-1999 was similar to the one in 2007, a plausible explanation of our results would be that parents are changing their aspirations for daughters due to their exposure to female health personnel.

Overall, the evidence suggest that PROGRESA's beneficiaries have increased their aspirations for their children's education, and this effect seems to be driven by increases in the aspirations for daughters, not for sons. Although this is an interesting result, it does not enable us to pinpoint the driving force behind the change. In the following subsection, we explore the role of exposure to doctors and nurses as a possible channel for increasing the educational aspirations of the poor.

\subsection{The effect of differential exposure to educated professionals on aspi- rations}

Exploiting the design of PROGRESA, we divide the sample into two groups with different levels of mandated exposure to nurses and doctors. We consider high-exposure households to be those with children less than five years of age and that must go to the health clinics at least four times per year. Furthermore, we consider low-exposure households to be those with no children less than five years of age and that are required to attend health clinics only once or twice per year. ${ }^{15}$

To identify the effect of differential exposure to educated professionals on parents' aspirations for their children's education, we need to control for any systematic variation to the aspirations of households with high exposure in the treatment villages that are correlated

\footnotetext{
${ }^{15}$ We consider only these two categories because we did not find any differential effect of exposure between households with children less than two years of age and households with children 2-5. Results are available upon request. Furthermore, since the aspirations questions in rounds three and four were asked only for children 6-16 years old, we cannot compare households with children less than seventeen years of age and households with no children less than seventeen years of age.
} 
with, but not due to, the introduction of PROGRESA. We do this using a "differencesin-differences-in-differences" (or triple difference) estimator as in Gruber (1994). First, we include a fixed time effect to capture any trend in the aspirations of the households. Second, we control for differences in aspirations in treatment villages with respect to control villages including a treatment village dummy. Third, we control for changes over time in treatment villages interacting a time dummy with a treatment village dummy. Thus, we estimate the change in average aspirations before and after the introduction of PROGRESA of households with different mandated exposure to highly educated professionals in treatment villages relative to control villages. The triple difference estimator captures all variation in aspirations specific to high-exposure households (relative to low-exposure households) in the treatment villages (relative to the control villages) six months and one year after the start of PROGRESA (relative to before the introduction of PROGRESA). As Gruber (1994) points out, the identifying assumption of this triple difference estimator is only that there are no contemporaneous shocks that affect the aspirations of the highexposure households relative to the low-exposure households in the same village-time at the start of PROGRESA.

By focusing on these two subgroups of households, we are aware that we are compromising the virtues of PROGRESA's experimental design. In Table 4, we show descriptive statistics of households in both treatment and control groups by level of mandated exposure at baseline. High-exposure households (i.e., with children less than five) are, on average, "younger" than low-exposure households (i.e., without children less than five). Also, highexposure households have fewer adults and more children than low-exposure households. The last two columns of Table 4 show that high- and low-exposure households are similar across treatment and control villages.

Treatment households with high exposure receive, on average, lower cash transfers than do treatment households with low exposure, and this difference is statistically significant. ${ }^{16}$ The difference in the amount of cash received is explained by the fact that households with children less than five have younger children. This implies that these households have fewer

\footnotetext{
${ }^{16}$ The cash transfers (educational and health components) presented in Table 4 are calculated considering the household's demographic structure and assuming that each household complies with all of PROGRESA's requirements. Considering this measure, high-exposure households receive, on average, 32 pesos less per month than do low-exposure households.
} 
children of school age who would be eligible to receive the educational cash transfers, which constitute the largest component of PROGRESA's transfers. Despite these differences, the monthly income (not including trasfers) of high- and low-exposure households is not very different, and the null that the monthly income of high- and low-exposure households is the same cannot be rejected. Thus, the marginal utility of the cash transfers may be higher for low-exposure households.

Column (iii) of Table 5 reports in rows 4 and 10 the double difference estimators for all children after six months following the start of the program for high- and low-exposure households, respectively. PROGRESA seems to have had an impact on parental aspirations for high-exposure households but not for low-exposure ones. In fact, panel C, column (iii), row 13, of Table 5 reports, highlighted in yellow, the triple difference estimator six months after the implementation of PROGRESA. Average aspirations of high-exposure households relative to low-exposure households in treatment villages relative to control villages are a third of a school year higher six months after the start of the program. This difference is statistically significant and suggests that aspirations are not driven by a "PROGRESA effect" but by exposure to highly educated professionals given that lowexposure households receive, on average, more cash from PROGRESA's transfers than do high-exposure households. Analyzing daughters and sons separately, we find a similar story.

One year after the start of the program, however, the double difference estimators reported in columns (iii), (vi), (ix), rows 5 and 11, for high- and low-exposure households, respectively, show that PROGRESA increased the parental aspirations for both types of households. This is particularly true in the case of daughters. Indeed, as shown by the triple difference estimators highlighted in yellow in panel C, row 14 of Table 5, there is not a statistically significant difference in the average aspirations of high-exposure households relative to low-exposure households in treatment villages relative to control villages a year after the start of the program for either all children, daughters, or sons.

Focusing on the case of daughters, the data seems to suggest that the aspirations of parents from low-exposure households have caught up with those of parents from highexposure households. As shown in Table 5, column (vi), row 6, the difference in the average change in aspirations of high-exposure households six months and one year after the start 
of PROGRESA is not statistically different from zero. On the other hand, as can be seen in Table 5, column (vi), row 12, the difference in the average change in aspirations of lowexposure households six months and one year after the start of PROGRESA is negative and statistically different from zero. This suggests that it is the amount of exposure (i.e., the number of meetings) that affects aspirations and not the frequency of these meetings.

Overall, results seem to suggest that mandated exposure to nurses and doctors has a positive effect on parental aspirations. Furthermore, it seems that it is the amount and not the frequency of exposure that drives the change in parental aspirations. If it were the case that, because they were beneficiaries, parents felt compelled to respond in a certain way, both types of beneficiaries would change their answers after the start of the program. Also, if the force behind the change in aspirations was an income effect due to the transfers, then the households that received higher transfer amounts (those with older children) should be the ones reporting higher aspirations. Finally, if the parents were changing there aspirations based on a correctly estimated present-discounted value of schooling, then the educationconditional cash transfer may have been greater for low-exposure households. Indeed, as the benefits of the program were granted by the government for a three year period only, low-exposure households have a greater incentive to overstate their educational aspirations, given that they would be gaining the most in terms of the education-conditional cash transfers. In fact, had the three years promise applied, by the time the children of highexposure households had reached the grade to start receiving the transfer, the program would have already been discontinued. Only in the case in which there had been $100 \%$ certainty that the program would have been continued for a longer time period, highexposure households would have had an incentive to overstate their aspirations. This last case seems highly unlikely as, at that time in Mexico, social programs used to disappear as soon as there was a change in administration.

In order to control for the differences in observable household characteristics between 
high- and low-exposure households we run the following regression: ${ }^{17}$

$$
\begin{aligned}
A S P_{i v t}= & \gamma+\delta_{1} X_{i v t}+\delta_{2} \tau_{t}+\delta_{3} T_{v}+\delta_{4} E X_{i}+ \\
& \delta_{5}\left(\tau_{t} \times T_{v}\right)+\delta_{6}\left(\tau_{t} \times E X_{i}\right)+\delta_{7}\left(T_{v} \times E X_{i}\right)+ \\
& \delta_{8}\left(\tau_{t} \times T_{v} \times E X_{i}\right)+\xi_{i v t}
\end{aligned}
$$

where, $A S P_{i v t}$ denotes the educational aspirations of the parents of household $i$ in village $v$ at time $t ; X_{i v t}$ is a vector of observable household characteristics that controls for differences between households with high and low exposure; ${ }^{18} \tau_{t}$ is a time dummy; and $T_{v}$ is a village dummy that equals one for households in treatment villages; $E X_{i}$, is a dummy that equals one for households with high exposure to health professionals; and $\xi_{i v t}$ is an idiosyncratic error term.

The similarities between this regression and the results presented in Table 5 are straightforward. The fixed effects control for the time-series changes in aspirations $\left(\delta_{2}\right)$, the timeinvariant characteristics of the treatment villages $\left(\delta_{3}\right)$, and the time-invariant characteristics of the high-exposure households $\left(\delta_{4}\right)$. The second-level interactions control for changes over time in the treatment villages $\left(\delta_{5}\right)$, changes over time for the high-exposure households $\left(\delta_{6}\right)$, and time-invariant characteristics of the high-exposure households in the treatment villages $\left(\delta_{7}\right)$.

The third-level interaction, $\delta_{8}$, is the coefficient of interest. It captures all variation in aspirations specific to the high-exposure households (relative to the low-exposure households) in the treatment villages (relative to the control villages) six months or one year after the introduction of PROGRESA (relative to before the introduction of PROGRESA).

\footnotetext{
${ }^{17}$ If there were to be unobservable characteristics that would cause high-exposure parents to have their aspirations affected differently by PROGRESA than low-exposure, we would not be able to detect such change and we would instead attribute it to high- or low- exposure to professionals. Nevertheless, it is unclear what these unobservable characteristics would be and whether they would cause a higher increase or decrease in aspirations for high-exposure parents versus low-exposure. For example, consider responsiveness to the program (i.e., to its economic incentives) as a possible unobservable variable. Younger and better educated households may be more responsive because they are used to be taught. On the other hand, these same households may be less responsive because they think they already know how to take care of their lives.

${ }^{18}$ The control variables included are the head's age, his educational level, whether he is literate, whether he is indigenous, the spouse's age, her educational level, whether she is literate, whether she is indigenous, the number of male and female adults, the number of male and female children, the birth spacing between the first and second child, and the household's monthly income.
} 
Table 6 shows the estimates of regression (2) six months (Panel A) and one year (Panel B) after the start of PROGRESA. The first row of Table 6, Panel A, presents the estimates of the third-level interaction, $\delta_{8}$ (i.e., the effect of exposure six months after the start of PROGRESA), whereas the second row presents the estimates of the PROGRESA effect for low-exposure households, $\delta_{5}$. The coefficients in columns (1), (5) and (9) correspond exactly to the coefficients in Table 5, row 13 (for the exposure effect) and row 10 (for the PROGRESA effect on low-exposure households), columns (iii), (iv), and (ix). Introducing additional household characteristics does not have a sizeable impact on either the exposure effect coefficient or the coefficient denoting the PROGRESA effect on low-exposure households. Independently of the specification, differential exposure seems to increase aspirations for all children by a third of a school year six months after the start of the program.

In column 2, we control for the parents' highest educational level in years. The magnitude of the coefficients indicates that, ceteris paribus, being exposed to educated professionals leads to the same increase in aspirations for children as would be associated with parents who had two extra years of schooling $\left(\frac{0.380}{0.179}=2.1\right)$. Thus, exposure to educated professionals seems to have almost the same effect on aspirations as average parental education (three years). Overall, differential exposure seems to be what matters since there is no statistically significant effect of PROGRESA per se. Considering daugthers only, differential exposure seems to increase aspirations by half of a school year six months after the start of the program. For the case of sons, differential exposure seems to increase aspirations by a quarter of a school year; however, this effect is not statistically significant.

Table 6, Panel B, shows similar estimates one year after the start of PROGRESA. The coefficients in columns (1), (5), and (9) correspond exactly to the coefficients in Table 5, row 14 (for the exposure effect) and row 11 (for the PROGRESA effect on low-exposure households), columns (iii), (iv), and (ix). Introducing additional household characteristics does not have a sizeable impact on the exposure effect. For all children, daughters and sons, the coefficient measuring the exposure effect is close to zero and not statistically significant. We do observe an effect of PROGRESA on low-exposure households for some specification for the case of daughters. This effect might be explained by the possibility that parental aspirations in low-exposure households have caught up with those of the 
high-exposure households. However, in all the other cases the PROGRESA effect on lowexposure households is never significant.

Overall, our findings seem to be robust to the inclusion of controls in the regression specification. Thus, mandated exposure to nurses and doctors appears to have a positive effect on parental aspirations, and the data seems to suggest that might the amount and not the frequency of exposure that drives the change in parental aspirations.

\subsection{Alternative aspiration outcomes}

An increase of 0.3 or 0.5 years of schooling may be difficult to interpret. Thus, instead of converting the data on aspirations into years of schooling, we created the variable "at least college," a dummy that equals one if the respondent aspires to at least 16 years of schooling for her children. ${ }^{19}$ Working with this variable allows us to see what proportion of households changed their responses as a result of differential mandated exposure to nurses and doctors. These results, in turn, may be easier to interpret than the changes in aspirations in years of schooling, and may help us understand what is driving the increases of 0.3 or 0.5 years of schooling.

As shown in Figure 1, at baseline, the proportion of households aspiring for their children to finish at least college is higher for the control group than for treatment group. However, at six months and one year after the start of the program, this proportion is greater for households in the treatment group.

We first consider the effect of PROGRESA on raising the proportion of parents who would like their children to complete at least college. Table 7 , row 1 , shows that, at baseline, more than $25 \%$ of the households want their children to at least complete college. The program seems to increase by $15 \%\left(\frac{0.040}{0.264} 100\right)$ and $19 \%\left(\frac{0.050}{0.264} 100\right)$ the proportion of parents who aspire for their children to finish college six months and a year after the start of the program, respectively. The effects are larger for daughters: the program seems to

\footnotetext{
${ }^{19}$ We do not consider the variable "at least primary education" and "at least secondary education" because more than $99 \%$ and $90 \%$ of the respondents declared that they wanted their children to at least finish their primary and secondary education, respectively. Given that the proportions were already high, the introduction of PROGRESA did not have any sizeable effect on modifying them. Also, we do not consider the results for the variable "at least technical school" because the proportion of households that aspired for their children complete at least a technical degree was low (less than 13\%) and was not affected by PROGRESA. Finally, results for "at least high school" are similar to the ones reported below on "at least college" and are available upon request.
} 
increase by $20 \%\left(\frac{0.046}{0.228} 100\right)$ and $25 \%\left(\frac{0.057}{0.228} 100\right)$ the proportion of parents who aspire for their daughters to finish college six months and a year after the start of the program, respectively. Although these increments are statistically significant for daughters, there is no significant impact for sons.

We now consider the effect of exposure on raising the proportion of parents who would like their children to complete at least college. Table 8 shows the results. About $25 \%$ of highexposure households and $30 \%$ of low-exposure households declared that they wanted their children to finish at least college. Six months after the start of the program, we see, again, a differential impact on parental aspirations. As summarized by the triple difference estimator in row $13,7 \%$ more of high-exposure households that received PROGRESA declared that they wanted their children to at least finish college. This $7 \%$ increase corresponds to a $29 \%\left(\frac{0.069}{0.242} 100\right)$ increase in the proportion of parents who aspire for their children to finish college. When looking separately at daughters and sons, results are similar, and the triple difference estimator shows a statistically significant increase of $8 \%$ for daughters and $6 \%$ for sons. This effect corresponds to a $40 \%$ (24\%) increase in the proportion of parents who aspire for their daughters (sons) to finish high school. One year after the start of the program, we see, again, the catch up effect, and, hence, the triple difference estimator decreases in magnitude and becomes not statistically significant.

Thus, it seems to be the case that the increase in parental aspirations of 0.3 schooling years, due to exposure to educated professionals, is the result of a $29 \%$ increase in the proportion of households that aspire to see their children finishing college. When looking only at daughters, increases are much higher. The results of the "at least" variables are robust to the inclusion of controls in the regression. ${ }^{20}$

\section{Robustness checks}

\subsection{Age effect}

Table 9 reports regressions similar to those in Table 6 . The difference is that, in Table 9 , we added a triple interaction that is intended to capture a possible age effect. This allows

\footnotetext{
${ }^{20}$ Results are available upon request.
} 
us to check whether parental aspirations about their children's education depend on their children's age. Hence, in order to control for a possible age component, we interact $\tau_{t}$, a time dummy, with $T_{v}$, the dummy variable that equals one for households in treatment localities, with the age of the youngest child.

We use the age of the youngest child for two reasons. First, we need a measure at the household level because our aspirations measure is built at the household level. Second, we need to be consistent about the way in which we construct the exposure dummy, which divides households into low- and high-exposure based on the age of the youngest child. Table 9 shows that the results do not change once we control for a possible age component and that such a component is very close to zero and is not statistically significant. Thus, there does not seem to be an age effect. ${ }^{21}$

\subsection{Children's health and parental aspirations}

In section 4.2 we explored the effect of differential exposure to educated professionals on aspirations by comparing households with high and low exposure to professionals. A possible concern could be that visits to the health clinics not only expose parents to professionals, but also enable children to get health treatments in the mean time. These treatments may improve children's health status and so have an impact on the educational aspirations of the parents, other than through exposure to professionals. We may think of a simple human capital argument: the healthier the children, the more likely parents wish to invest in them since their life horizon increases.

The ideal experiment to isolate the causal impact of exposure to professionals on educational aspirations would entail visits to professionals that are utterly useless in themselves. In this experiment, we would be sure that the effect would simply come from interacting with trained professionals, not from a treatment these professionals may give. As such an experiment is not available, we study if there is any relationship between chidren's health and educational aspirations of the parents. Since data on children being ill is available in round three, we consider households living in control villages as they are not influenced by

\footnotetext{
${ }^{21}$ We also run a regression with time and households fixed effects considering only the control group (which is not affected by PROGRESA) with aspirations as a dependent variable and age of the youngest child as explanatory variable. The coefficient associated with the age of the youngest is not statistically significant. The results are available upon request.
} 
their exposure to professionals, or by PROGRESA's conditionality requirements.

We consider two different children health measures: a dummy equal to one if the household had a child ill at most 3 days during the previous month, and a dummy equal to one if the household had a child ill at least 20 days during the previous month. The former intends to measure a minor illness, such as a simple cold, while the latter intends to measure a more serious illness that could have strong repercussions. ${ }^{22}$

Table 10 shows the results of running OLS regressions of parental aspirations on the children's health measures. Parental aspirations do not seem to be linked to their children's health status, independently of whether we consider a minor or a serious illness. These regressions do not have a causal interpretation and only intend to show that there does not seem to be any significant relationship between parents' educational aspirations and children's health. Thus, it does not seem that plausible that health improvements caused by visits to the health clinic have an impact on the educational aspirations of the parents.

\subsection{Falsification test}

In order to check whether our results are spurious, we perform the same analysis that we have conducted thus far on the non-eligible households. ${ }^{23}$ That is, we check whether the parental aspirations of those households that are not eligible to receive the benefits of PROGRESA, and, hence, are not required to send their children to school or regularly present at the health clinics for check-ups, are also changing.

Table 11 summarizes our results. As shown in columns (iii), (vi), and (ix), rows 4 and 5, for high-exposure households, and rows 10 and 11, for low-exposure households, after the start of PROGRESA, non-eligible parents did not change the aspirations that they had for their children. Consequently, the triple difference estimators reported in columns (iii), (vi), and (ix), rows 13 and 14, are not statistically different from zero, which indicates that neither after six months nor after one year from the start of PROGRESA did non-eligible parents change their aspirations for their children's education. All of these

\footnotetext{
${ }^{22}$ Regression results using different health measures (e.g. having a child ill at least 5, 10, and 15 days) show very similar results and are available upon request.

${ }^{23}$ Within every locality where the program is implemented, households are non-eligible to receive PROGRESA's benefits if they are above the poverty level as determined by discriminant analysis on census data.
} 
results are robust to the inclusion of controls in a regression framework. Hence, we can be confident that our findings are the result of the introduction of PROGRESA and not of some other circumstance that occurred in the treatment villages that may have been affecting households with children less than five years of age differently relative to households with older children.

\subsection{Identity of the respondent}

We exploit differences regarding the identity and the exposure to professionals of the survey respondent. In fact, mothers are not always the survey respondents. Nevertheless, they are the ones that take the children to the health clinic. Thus, mothers are the ones exposed the most to doctors and nurses. Hence, as a robustness check, we exploit the differences regarding the identity of the respondent in each household in order to identify the effect of differential exposure to educated professionals.

In particular, we consider only households where the mother is present. Using these households, we divide the sample into households in which the respondent of the questionnaire is the mother and households in which the respondent of the questionnaire is another household member. Table 12 shows the results considering data at baseline and at six months after the start of the program. For this table we consider only households in which the respondent is the mother both at baseline and six months after the start of the program, and households in which the respondent is not the mother both at baseline and six months after the start of the program. Table 13 shows the results considering data at baseline and at one year after the start of the program. For this table we consider only households in which the respondent is, and is not, the mother in all three survey rounds - baseline, six months and one year after the start of the program.

Columns (iii), (vi), and (ix) of Table 12 report in row 3 the double difference estimators for daughters and sons six months after the start of the program for households in which the respondent is the mother; row 6 shows the double difference estimators for households in which the respondent is not the mother. PROGRESA seems to have a positive and statistically significant effect on parental aspirations for households in which the respondent is the mother but not for households where the respondent is not the mother. Nevertheless, 
the triple difference estimators reported in row 7 are not very precise, due to the reduction in sample size, and hence are not statistically significant. Results in Table 13 are similar, but less precisely estimated and smaller in magnitude consistent with all previous results after one year of the start of the program.

\subsection{Alternative subsamples}

We consider alternative subsamples in order to analyze households with more comparable family structures. In particular, we focus on the following four subsamples: (i) households with exactly two children less than 11 years of age; (ii) households with exactly three children less than 11 years of age; (iii) households with one child of age five and other siblings; (iv) households with one child of age six and other siblings. For all four subsamples, we obtained similar results to those reported above for the whole sample. Nevertheless, when reducing the sample size, the variability increases causing the estimates to not always be statistically significant. ${ }^{24}$

\section{Educational aspirations and behavioral outcomes}

The fourth survey round contains information about the time each household member allocated to 18 different activities during the previous day. Because beneficiary households are influenced not only by their exposure to professionals, but also by PROGRESA's conditionality requirements (i.e., attending school and visiting the health clinic), it is not possible to isolate the impact that aspirations might have on behavioral outcomes such as the time spent by children studying and working. ${ }^{25}$ However, we are still able to check whether, for households living in control villages, there is any relationship between parental aspirations toward their children's education and the time their children spend doing school homework and working. We consider households from control villages because their behavior was not influenced by PROGRESA's conditionality requirements, since they were not receiving the benefits of the program.

\footnotetext{
${ }^{24}$ Regression results for the subsamples are available upon request.

${ }^{25}$ For example, an increase in school attendance could be caused by exposure to doctors and nurses as well as by the educational cash transfers received for attending school.
} 
Table 14 shows the results of running OLS regressions of the time used by children doing homework and working, on parental aspirations. In particular, Panel A of Table 14 shows that there is a positive and significant relationship between parents' educational aspirations and the number of minutes children spend doing their homework. In contrast, Panel B of Table 14 outlines a negative link between parents' educational aspirations and the number of minutes their children spend working at home or outside. These regressions however, do not have a causal interpretation. For example, children that do not work and spend their afternoons doing homeworks may do well in school, and this good performance may increase the educational aspirations their parents have for them. Still, the positive (for homework) and negative (for work) signs of the coefficients suggest that an increase in parental educational aspirations might result in a decrease in child labor and an increase in the time children spend studying.

\section{Conclusions}

Poverty almost certainly affects the way people think and make decisions (Duflo, 2006), which causes the poor to have limited aspirations, and, as a result, might cause them to underinvest in the education of their children thereby generating a self-sustaining poverty trap (Ray, 2006; Appadurai, 2004). Understanding if the aspirations of the poor can be increased and, if so, through which channel(s) is an important tool for reducing poverty.

This paper studies the effect of PROGRESA on poor parents' aspirations for the educational attainment of their children and explores the role of mandated exposure to educated professionals as a possible channel for increasing aspirations. First, we compare the outcomes of households that had been randomly selected to receive the benefits of PROGRESA against the outcomes of statistically similar households that had not been selected to participate in the program. We show that beneficiary parents have higher educational aspirations for their children of about a third of a school year than do non-beneficiary parents. When looking separately at daughters and sons, we find that the effect is mainly driven by daughters.

Then, we take advantage of the design of PROGRESA, which generates differential ex- 
posure to highly educated professionals. In fact, we consider high-exposure households to be those with children less than five years of age and that must present at the health clinics at least four times per year. We consider low-exposure households to be those without children less than five years of age and that are required to attend health clinics only once or twice per year. We estimate the change in average aspirations before and after the introduction of PROGRESA for households with high exposure to highly educated professionals (relative to households with low exposure) in treatment villages (relative to control villages). Average aspirations for all children of high-exposure households (relative to low-exposure households) in treatment villages (relative to control villages) are a third of a school year higher six months after the start of the program (relative to before its introduction). This difference is statistically significant and suggests that the channel through which parental aspirations are changing is the households' exposure to highly educated professionals. When considering daughters and sons separately, we find, again, that the effect is mainly driven by daughters. 2007 data on the gender of health personnel suggest that this result might be driven by the fact that the majority of the health personnel is female.

Interestingly, a year after the start of the program, the aspirations of parents from lowexposure households catch up to those of high-exposure households. Thus, aspirations seem to be affected by a minimum amount of exposure (i.e., a minimum number of meetings) and not by the frequency of exposure.

We also consider as an alternative aspiration variable the proportion of parents who declare that they want their children to finish at least college. On the one hand, this variable allows us to see the impact of the program on the proportion of households that aspire for college completion for their children. We find a $15 \%$ and a $19 \%$ increase in the proportion of parents who aspire for their children to finish college six months and a year after the start of the program, respectively. On the other hand, this variable allows us to see the impact of differential mandated exposure to doctors and nurses on the proportion of households that aspire for college completion for their children. Six months after the start of the program, the increase in parental aspirations of a third of a school year is driven by a $29 \%$ increase in the proportion of households that aspire to see their children finishing at least college. 
Our findings are robust to a number of robustness checks. In particular, our results do not seem to be due to an income effect from the cash transfers received by the households, nor by an age effect, nor by a health effect, nor because of some other circumstance occurring in the treatment villages that may have affected households with high exposure to doctors and nurses differently than households with low exposure. As an additional robustness check, we also exploit differences in the identity of the survey respondent in each household. PROGRESA seems to have a positive and statistically significant effect on parental aspirations for households in which the respondent is the mother but not for households where the respondent is not the mother.

Identifying a possible channel through which aspirations of the poor can be modified adds a new tool to the existing options that try to promote increased investments in human capital and productive assets as a means by which to escape poverty. Furthermore, policy makers could take advantage of their target population's exposure to educated professionals, which is generated by the design of the social program, to increase the aspirations of their beneficiaries by encouraging or requiring them to meet with the highly educated professionals a sufficient number of times. Finally, our findings suggest that, in highly segregated environments or in contexts in which there is low social interaction or lack of leaders, promoting exposure to external educated professionals may have important consequences with respect to the aspirations of the population.

Although we can provide evidence as to whether differential exposure affects aspirations, the data do not allow us to analyze whether higher aspirations affect parents' decisions about the education or labor of their children. Nevertheless, parents' educational aspirations seem to be positively related to the number of minutes children spend doing their school homeworks and negatively related to the time children spend working. This suggests that an increase in parents' educational aspirations might result in an increase in human capital investment and a decrease in child labor.

Future research will aim at getting a deeper understanding of the precise mechanism(s) through which aspirations change. The possible mechanisms suggested in the literature for why exposure to highly educated professionals could influence aspirations are many. First, according to Ray (2006), exposure stimulates social interactions, which, in turn, 
increase individuals' aspiration windows. Second, exposure causes information flows that allow individuals to learn about opportunities that they might engage in or the investment it takes to achieve the associated goals. Third, exposure increases the set of alternatives that people consider because they have bounded rationality. 


\section{References}

Appadurai, Arjun (2004), "The Capacity to Aspire," In Culture and Public Action, edited by Vijayendra Rao and Michael Walton. Stanford, California: Stanford University Press.

Barberis, Nicholas, Ming Huang, and Richard H. Thaler (2006), "Individual Preferences, Monetary Gambles, and Stock Market Participation: A Case of Narrow Framing," American Economic Review, 96(4), 1069-1090.

Becker, Gary S. (1995), "Human Capital and Poverty Alleviation," World Bank Human Resources Development and Operations Policy,Working Paper No. 52.

Berhman, Jere, and Petra E. Todd (1999), "Randomness in the Experimental Samples of PROGRESA (Education, Health, and Nutrition Program),” International Food Policy Research Institute, March.

Case, Anne C., and Lawrence F. Katz (1991), "The Company You Keep: The Effect of Family and Neighborhood on Disadvantaged Youths," NBER Working Paper No. 3705.

Conlisk, John (1996), "Why Bounded Rationality?" Journal of Economic Literature, 34(2), 669-700.

DellaVigna, Stefano (2009), "Psychology and Economics: Evidence from the Field," Journal of Economic Literature, 47(2), 315-372.

Duflo, Esther (2006), "Poor But Rational?" In Understanding Poverty, edited by Abhijit V. Banerjee, Roland Bérnabou and Dilip Mookherjee. New York: Oxford University Press.

Frank, Robert H. (1985), "The Demand for Unobservable and Other Nonpositional Goods," American Economic Review, 75(1), 101-116.

Frank, Robert H. (1997), "The Frame of Reference as a Public Good," Economic Journal, 107(445), 1832-1847.

Gabaix, Xavier, David Laibson, Guillermo Moloche, and Stephen Weinberg (2006), "Costly Information Acquisition: Experimental Analysis of a Boundedly Rational Model," American Economic Review, 96(4), 1043-1068. 
Genicot, Garance, and Debraj Ray (2009), "Aspirations, Inequality, Investment and Mobility," Georgetown University and New York University. Mimeo.

Gertler, Paul J. (2000), "Final Report: The Impact of PROGRESA on Health," International Food Policy Research Institute, November.

Goodman, Alissa, and Paul Gregg (2010), "Children's Educational Outcomes: the Role of Attitudes and Behaviours, from Early Childhood to Late Adolescence," Final Report for the Joseph Rowntree Foundation, Centre for Market and Public Organisation, University of Bristol, and Institute for Fiscal Studies.

Gould, Eric D., Victor Lavy, and Daniele Paserman (2009), "Sixty Years after the Magic Carpet Ride: The Long-Run Effect of the Early Childhood Environment on Social and Economic Outcomes," NBER Working Paper 14884.

Gregg, Paul, and Elizabeth Washbrook (2009), "The Socioeconomic Gradient in Child Outcomes: the Role of Attitudes, Behaviours and Beliefs. The Primary School Years," Report for the Joseph Rowntree Foundation, Centre for Market and Public Organisation, University of Bristol.

Gruber, Jonathan (1994), "The Incidence of Mandated Maternity Benefits," American Economic Review, 84(3), 622-641.

Gutman, Leslie M., and Rodie Akerman (2008a), "Aspirations and Attainment: a Review for the Social Exclusion Taskforce," Centre for Research on the Wider Benefits of Learning, Institute of Education, University of London.

Gutman, Leslie M., and Rodie Akerman (2008b), "Determinants of Aspirations," Centre for Research on the Wider Benefits of Learning, Institute of Education, University of London, Research Report No. 27.

Hoff, Karla, and Priyanka Pandey (2004), "Belief Systems and Durable Inequalities - An Experimental Investigation of Indian Caste," World Bank Policy Research Working Paper No. 3351.

Jensen, Robert T. (2010), "The (Perceived) Returns to Education and the Demand for Schooling," Quarterly Journal of Economics, 125(2), 515-548. 
Kahneman, Daniel (2003), "Maps of Bounded Rationality: Psychology for Behavioral Economics," American Economic Review, 93(5), 1449-1475.

Kling, Jeffrey R., Jeffrey B. Liebman, and Lawrence F. Katz (2007), "Experimental Analysis of Neighborhood Effects," Econometrica, 75, 83-119.

Macours, Karen, and Renos Vakis (2009), "Changing Households' Investments and Aspirations through Social Interactions: Evidence from a Randomized Transfer Program," World Bank Policy Research Working Paper No. 5137.

Mookherjee, Dilip, Stefan Napel, and Debraj Ray (2010), "Aspirations, Segregation and Occupational Choice," Journal of the European Economic Association, 8(2-3), 388-400.

Munshi, Kaivan, and Mark Rosenzweig (2005), "Traditional Institutions Meet the Modern World: Caste, Gender and Schooling Choice in a Globalizing Economy," Mimeo.

Parker, Susan W., Luis Rubalcava, and Graciela Teruel (2008), "Evaluating Conditional Schooling and Health Programs," In T. Paul Schultz and John A. Strauss (Eds.), Handbook of Development Economics vol. 4 (Amsterdam: Elsevier Science).

PROGRESA (1997), Programa de Educación, Salud y Alimentación. Poder Ejecutivo Federal.

PROGRESA (1999), Lineamientos Generales para la Operación del Programa de Educación, Salud y Alimentación. Documentos de Divulgación. Coordinación Nacional del Programa de Educación, Salud y Alimentación. México, D. F.

Rabin, Matthew, and Georg Weizsäcker (forthcoming), "Narrow Bracketing and Dominated Choices," American Economic Review.

Ray, Debraj (2006), "Aspirations, Poverty, and Economic Change," In Understanding Poverty, edited by Abhijit V. Banerjee, Roland Bérnabou and Dilip Mookherjee. New York: Oxford University Press.

Rubinstein, Ariel (1998), “Modeling Bounded Rationality," Cambridge: MIT Press.

Sánchez-Peña, Landy (2007), "Gender and Socioeconomic Residential Segregation in Mexico City," paper presented at the Population Association of America 2007 annual meeting. 
Skoufias, Emmanuel (2005), "PROGRESA and Its Impacts on the Human Capital and Welfare of Households in Rural Mexico," International Food Policy Research Institute Research Report No. 139.

Skoufias, Emmanuel, Benjamin Davis, and Sergio de la Vega (2001), "Targeting the Poor in Mexico: An Evaluation of the Selection of Households into PROGRESA," World Development, 29, 1769-1984.

Teruel, Graciela, and Luis Rubalcava (2007), "Attrition in Progresa," Mimeo. 
Figure 1: Proportion of Households that Aspire for their Children to Complete at Least College

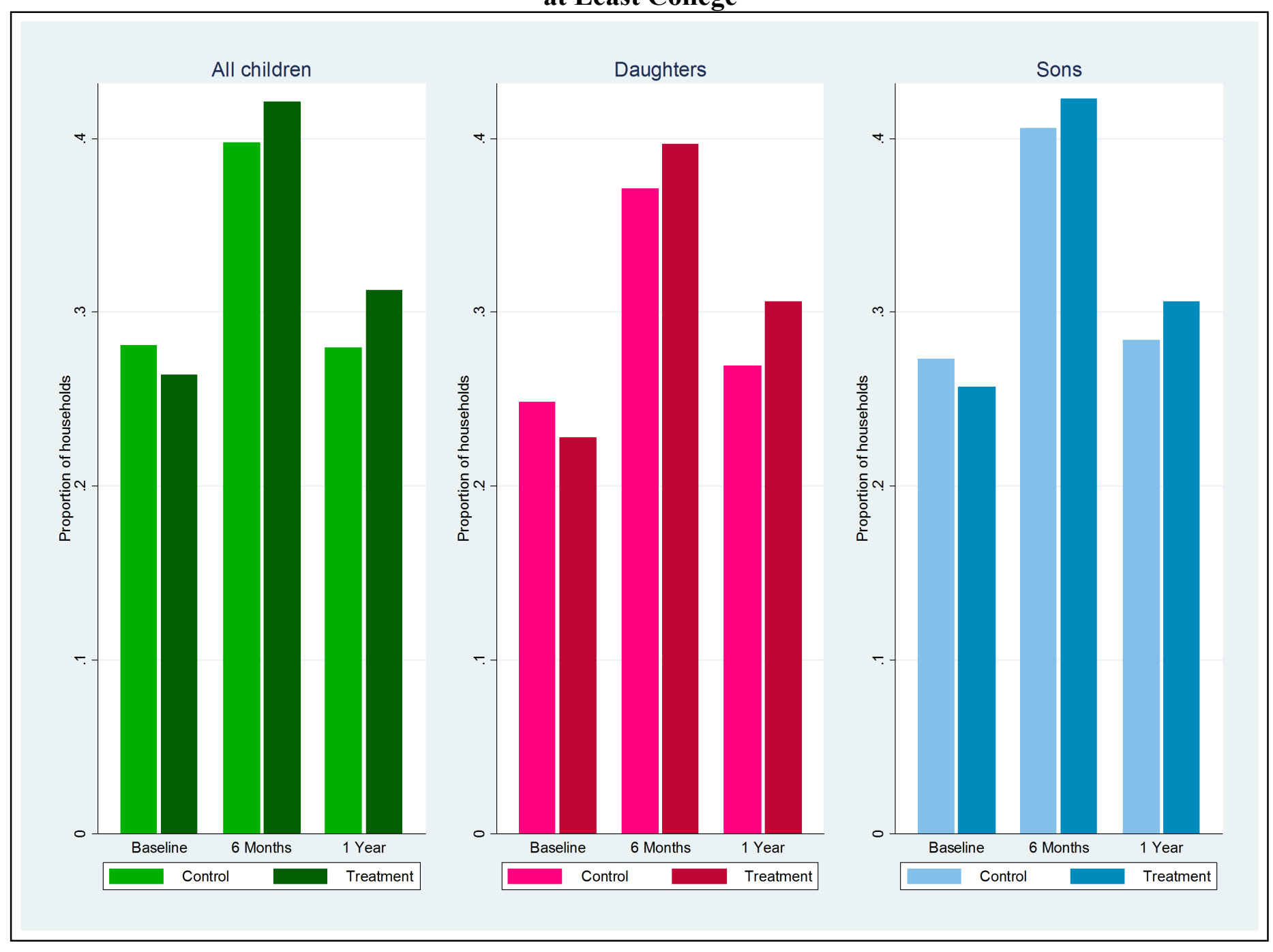


Table 1: Descriptive Statistics by Treatment Status, Fixing Household Structure as of Baseline (1997)

\begin{tabular}{|c|c|c|c|c|}
\hline & \multirow[b]{2}{*}{ Obs. } & \multicolumn{2}{|c|}{ Mean } & \multirow[b]{2}{*}{ T-stat } \\
\hline & & Treatment & Control & \\
\hline \multicolumn{5}{|l|}{ a) Characteristics of the head of the household } \\
\hline Age & 8,089 & 41.66 & 42.39 & $-2.09 * *$ \\
\hline Educational level in years & 8,078 & 2.88 & 2.78 & 0.85 \\
\hline Literate & 8,100 & 0.72 & 0.71 & 0.26 \\
\hline Indigenous & 8,096 & 0.41 & 0.42 & -0.07 \\
\hline \multicolumn{5}{|l|}{ b) Characteristics of the spouse of the head of the household } \\
\hline Age & 7,361 & 36.70 & 36.86 & -0.59 \\
\hline Educational level in years & 7,348 & 2.65 & 2.63 & 0.16 \\
\hline Literate & 7,359 & 0.63 & 0.62 & 0.56 \\
\hline Indigenous & 7,353 & 0.41 & 0.41 & 0.00 \\
\hline \multicolumn{5}{|l|}{ c) Characteristics of the household } \\
\hline Mean age of adults & 8,104 & 36.16 & 36.55 & -1.46 \\
\hline Mean educational level of adults & 8,103 & 3.24 & 3.16 & 0.66 \\
\hline Proportion of literate adults & 8,103 & 0.71 & 0.70 & 0.48 \\
\hline Proportion of indigenous adults & 8,095 & 0.40 & 0.41 & -0.06 \\
\hline Income & 8,106 & 922.90 & 946.03 & -0.56 \\
\hline \multicolumn{5}{|l|}{ d) Household structure } \\
\hline Size & 8,106 & 6.75 & 6.75 & -0.02 \\
\hline Number of adults & 8,106 & 2.68 & 2.68 & 0.15 \\
\hline Number of female adults & 8,106 & 1.37 & 1.38 & -0.44 \\
\hline Number of male adults & 8,106 & 1.31 & 1.29 & 0.83 \\
\hline Proportion of male adults & 8,102 & 0.48 & 0.48 & 0.61 \\
\hline Number of children & 8,106 & 4.06 & 4.06 & -0.10 \\
\hline Number of female children & 8,106 & 1.96 & 2.01 & -1.13 \\
\hline Number of male children & 8,106 & 2.09 & 2.05 & 1.25 \\
\hline Proportion of male children & 8,069 & 0.52 & 0.51 & $2.20 * *$ \\
\hline Proportion of households with children less than 5 years old & 8,106 & 0.65 & 0.63 & 1.18 \\
\hline Proportion of households with children between 2 and 5 years old & 8,106 & 0.34 & 0.33 & 0.91 \\
\hline Proportion of households with children less than 2 years old & 8,106 & 0.32 & 0.31 & 0.54 \\
\hline \multicolumn{5}{|l|}{ Birth spacing between children } \\
\hline - between 1st and 2nd child & 7,326 & 3.23 & 3.35 & -1.24 \\
\hline - between 2nd and 3rd child & 6,423 & 2.90 & 2.88 & 0.32 \\
\hline - between 3rd and 4th child & 4,884 & 2.80 & 2.81 & -0.19 \\
\hline - between 4th and 5th child & 3,240 & 2.64 & 2.72 & -1.29 \\
\hline - between 5th and 6th child & 1,953 & 2.54 & 2.63 & -1.25 \\
\hline - between 6th and 7th child & 1,014 & 2.38 & 2.43 & -0.61 \\
\hline - between 7th and 8th child & 467 & 2.34 & 2.31 & 0.30 \\
\hline - between 8th and 9th child & 184 & 2.12 & 2.19 & -0.37 \\
\hline - between 9th and 10th child & 94 & 1.95 & 1.76 & 0.89 \\
\hline
\end{tabular}

Note: T-statistics of difference in means computed clustering at the village level. Differences significant at the $* 10 \%$, $* * 5 \%$, or $* * * 1 \%$ level. 
Table 2: Average Aspirations per Household Before and After the Start of PROGRESA

\begin{tabular}{|c|c|c|c|c|c|c|c|c|c|}
\hline & \multicolumn{3}{|c|}{ All children } & \multicolumn{3}{|c|}{ Daughters } & \multicolumn{3}{|c|}{ Sons } \\
\hline & $\begin{array}{l}\text { Treatment } \\
\text { (i) }\end{array}$ & $\begin{array}{l}\text { Control } \\
\text { (ii) }\end{array}$ & $\begin{array}{l}\mathrm{T}-\mathrm{C} \\
\text { (iii) }\end{array}$ & $\begin{array}{l}\text { Treatment } \\
\text { (iv) }\end{array}$ & $\begin{array}{l}\text { Control } \\
\text { (v) }\end{array}$ & $\begin{array}{l}\mathrm{T}-\mathrm{C} \\
\text { (vi) }\end{array}$ & $\begin{array}{l}\text { Treatment } \\
\text { (vii) }\end{array}$ & $\begin{array}{l}\text { Control } \\
\text { (viii) }\end{array}$ & $\begin{array}{l}\text { T - C } \\
\text { (ix) }\end{array}$ \\
\hline $\begin{array}{l}\text { 1. Parental aspirations before } \\
\text { the start of PROGRESA }\end{array}$ & $\begin{array}{l}11.662 \\
(0.101)\end{array}$ & $\begin{array}{l}11.781 \\
(0.119)\end{array}$ & $\begin{array}{l}-0.119 \\
(0.156)\end{array}$ & $\begin{array}{l}11.324 \\
(0.098)\end{array}$ & $\begin{array}{l}11.484 \\
(0.114)\end{array}$ & $\begin{array}{l}-0.160 \\
(0.151)\end{array}$ & $\begin{array}{l}11.552 \\
(0.100)\end{array}$ & $\begin{array}{l}11.674 \\
(0.117)\end{array}$ & $\begin{array}{l}-0.123 \\
(0.154)\end{array}$ \\
\hline $\begin{array}{l}\text { 2. Parental aspirations after } 6 \text { months of } \\
\text { the start of PROGRESA }\end{array}$ & $\begin{array}{l}13.053 \\
(0.078)\end{array}$ & $\begin{array}{c}12.861 \\
(0.1)\end{array}$ & $\begin{array}{c}0.192 \\
(0.126)\end{array}$ & $\begin{array}{l}12.944 \\
(0.083)\end{array}$ & $\begin{array}{l}12.721 \\
(0.105)\end{array}$ & $\begin{array}{c}0.223 \\
(0.133)\end{array}$ & $\begin{array}{l}13.056 \\
(0.080)\end{array}$ & $\begin{array}{l}12.912 \\
(0.099)\end{array}$ & $\begin{array}{c}0.145 \\
(0.128)\end{array}$ \\
\hline $\begin{array}{l}\text { 3. Parental aspirations after } 1 \text { year of } \\
\text { the start of PROGRESA }\end{array}$ & $\begin{array}{l}12.558 \\
(0.078)\end{array}$ & $\begin{array}{l}12.409 \\
(0.085)\end{array}$ & $\begin{array}{c}0.149 \\
(0.116)\end{array}$ & $\begin{array}{l}12.509 \\
(0.082)\end{array}$ & $\begin{array}{l}12.310 \\
(0.093)\end{array}$ & $\begin{array}{c}0.199 \\
(0.124)\end{array}$ & $\begin{array}{l}12.497 \\
(0.079)\end{array}$ & $\begin{array}{l}12.408 \\
(0.087)\end{array}$ & $\begin{array}{c}0.089 \\
(0.118)\end{array}$ \\
\hline $\begin{array}{l}\text { 4. Change in mean aspirations } \\
\text { baseline vs. } 6 \text { months }\end{array}$ & $\begin{array}{c}1.391 \\
(0.097)\end{array}$ & $\begin{array}{c}1.080 \\
(0.131)\end{array}$ & $\begin{array}{c}0.311 \\
(0.163)\end{array}$ & $\begin{array}{c}1.620 \\
(0.101)\end{array}$ & $\begin{array}{c}1.237 \\
(0.130)\end{array}$ & $\begin{array}{c}0.383 \\
(0.164)\end{array}$ & $\begin{array}{c}1.505 \\
(0.099)\end{array}$ & $\begin{array}{c}1.237 \\
(0.135)\end{array}$ & $\begin{array}{c}0.267 \\
(0.167)\end{array}$ \\
\hline $\begin{array}{l}\text { 5. Change in mean aspirations } \\
\text { baseline vs. } 1 \text { year }\end{array}$ & $\begin{array}{c}0.896 \\
(0.095)\end{array}$ & $\begin{array}{c}0.628 \\
(0.124)\end{array}$ & $\begin{array}{c}0.268 \\
(0.156)\end{array}$ & $\begin{array}{c}1.185 \\
(0.100)\end{array}$ & $\begin{array}{c}0.826 \\
(0.125)\end{array}$ & $\begin{array}{c}0.360 \\
(0.160)\end{array}$ & $\begin{array}{c}0.946 \\
(0.095)\end{array}$ & $\begin{array}{c}0.733 \\
(0.123)\end{array}$ & $\begin{array}{c}0.212 \\
(0.156)\end{array}$ \\
\hline
\end{tabular}

Note: Robust standard errors clustered at the village level in parenthesis.

Table 3: Average Aspirations per Household Before and After the Start of PROGRESA

\begin{tabular}{|c|c|c|c|c|c|c|c|c|c|}
\hline & \multicolumn{3}{|c|}{ All children } & \multicolumn{3}{|c|}{ Daughters } & \multicolumn{3}{|c|}{ Sons } \\
\hline & (1) & $(2)$ & (3) & (4) & (5) & (6) & (7) & $(8)$ & (9) \\
\hline \multicolumn{10}{|l|}{ Panel A: Impact after 6 months } \\
\hline PROGRESA effect & $\begin{array}{c}0.311^{*} \\
(0.163)\end{array}$ & $\begin{array}{c}0.313 * \\
(0.163)\end{array}$ & $\begin{array}{c}0.310 * \\
(0.163)\end{array}$ & $\begin{array}{c}0.383 * * \\
(0.164)\end{array}$ & $\begin{array}{c}0.382 * * \\
(0.164)\end{array}$ & $\begin{array}{c}0.386 * * \\
(0.164)\end{array}$ & $\begin{array}{c}0.267 \\
(0.167)\end{array}$ & $\begin{array}{c}0.275 * \\
(0.167)\end{array}$ & $\begin{array}{c}0.267 \\
(0.167)\end{array}$ \\
\hline Parents' highest educational level in years & & $\begin{array}{c}0.165 * * * \\
(0.013)\end{array}$ & & & $\begin{array}{c}0.167 * * * \\
(0.014)\end{array}$ & & & $\begin{array}{c}0.162^{* * *} \\
(0.014)\end{array}$ & \\
\hline Controls for unbalanced household characteristics ${ }^{1}$ & No & No & Yes & No & No & Yes & No & No & Yes \\
\hline Probability value for controls ${ }^{2}$ & --- & --- & 0.001 & --- & --- & 0.066 & --- & --- & 0.023 \\
\hline Obs. & 15,438 & 15,433 & 15,369 & 13,415 & 13,411 & 13,349 & 13,801 & 13,797 & 13,738 \\
\hline $\mathrm{R}^{2}$ (overall) & 0.043 & 0.063 & 0.044 & 0.055 & 0.070 & 0.055 & 0.050 & 0.070 & 0.050 \\
\hline \multicolumn{10}{|l|}{ Panel B: Impact after 1 year } \\
\hline PROGRESA effect & $\begin{array}{c}0.268^{*} \\
(0.156)\end{array}$ & $\begin{array}{c}0.269 * \\
(0.156)\end{array}$ & $\begin{array}{c}0.266 * \\
(0.156)\end{array}$ & $\begin{array}{c}0.360 * * \\
(0.160)\end{array}$ & $\begin{array}{c}0.361^{* *} \\
(0.161)\end{array}$ & $\begin{array}{c}0.360 * * \\
(0.160)\end{array}$ & $\begin{array}{c}0.212 \\
(0.156)\end{array}$ & $\begin{array}{c}0.211 \\
(0.156)\end{array}$ & $\begin{array}{c}0.212 \\
(0.156)\end{array}$ \\
\hline Parents' highest educational level in years & & $\begin{array}{c}0.156^{* * *} \\
(0.014)\end{array}$ & & & $\begin{array}{c}0.155^{* * *} \\
(0.015)\end{array}$ & & & $\begin{array}{c}0.155^{* * *} \\
(0.014)\end{array}$ & \\
\hline Controls for unbalanced household characteristics ${ }^{1}$ & No & No & Yes & No & No & Yes & No & No & Yes \\
\hline Probability value for controls ${ }^{2}$ & --- & --- & 0.038 & --- & --- & 0.283 & --- & --- & 0.025 \\
\hline Obs. & 15,137 & 15,131 & 15,078 & 13,324 & 13,319 & 13,268 & 13,641 & 13,637 & 13,583 \\
\hline $\mathrm{R}^{2}$ (overall) & 0.018 & 0.037 & 0.019 & 0.029 & 0.050 & 0.030 & 0.020 & 0.040 & 0.021 \\
\hline
\end{tabular}

Note: Robust standard errors clustered at the village level in parenthesis. Each individual coefficient is statistically significant at the *10\%, $* * 5 \%$, or $* * * 1 \%$ level.

${ }^{1}$ Age of the head of the household and proportion of male children are included. ${ }^{2}$ Probability value of joint $\mathrm{F}$ test for exclusion of all control variables. 
Table 4: Descriptive Statistics by Treatment Status and Household Composition, Fixing Household Structure as of Baseline (1997)

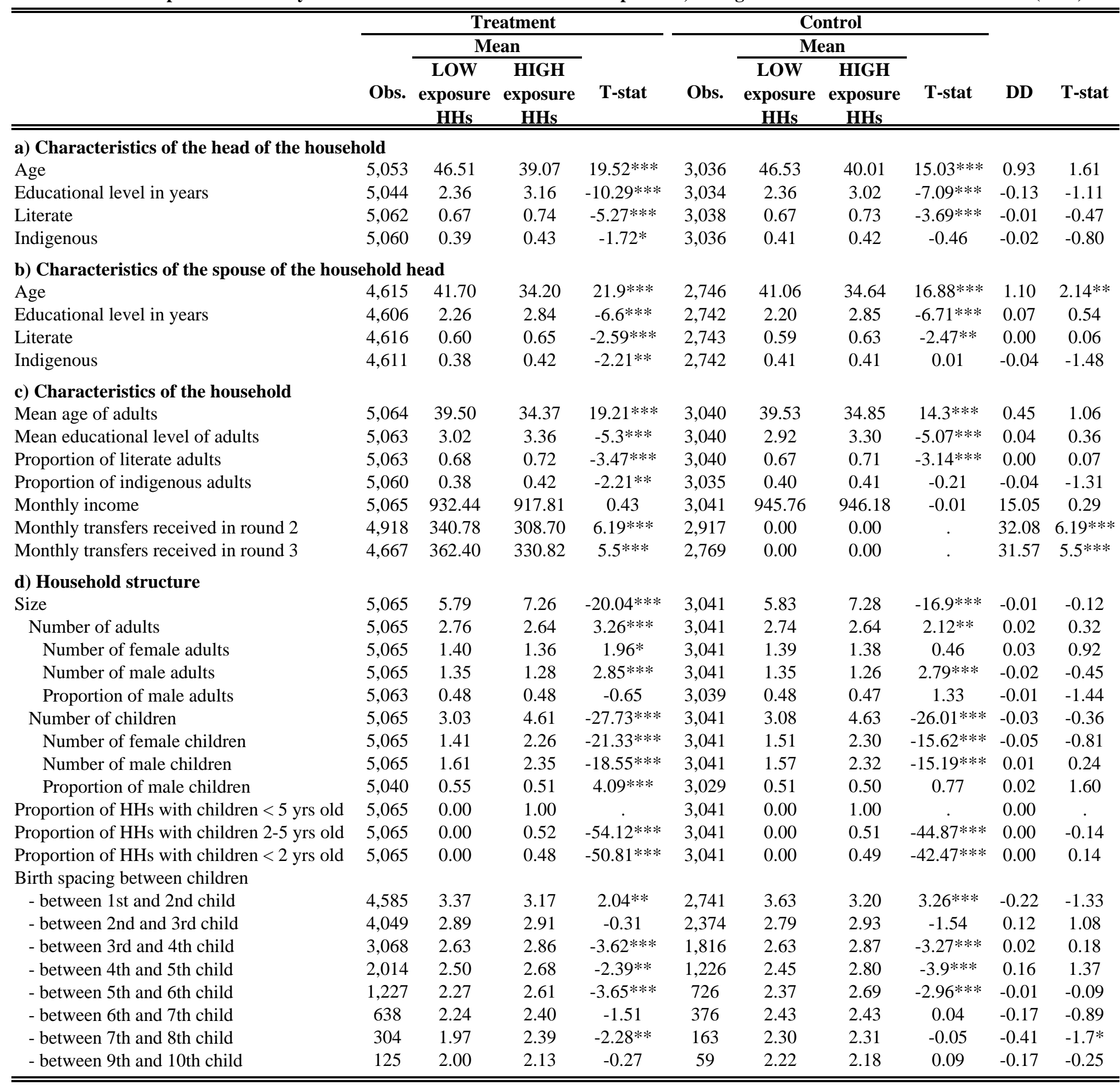

Note: T-statistics of difference in means computed clustering at the village level. Differences significant at the $* 10 \%$, $* * 5 \%$, or $* * * 1 \%$ level. 
Table 5: Average Aspirations per Household Before and After the Start of PROGRESA by Type of Household

\begin{tabular}{|c|c|c|c|c|c|c|c|c|c|}
\hline & \multicolumn{3}{|c|}{ All children } & \multicolumn{3}{|c|}{ Daughters } & \multicolumn{3}{|c|}{ Sons } \\
\hline & $\begin{array}{l}\text { Treatment } \\
\text { (i) }\end{array}$ & $\begin{array}{l}\text { Control } \\
\text { (ii) }\end{array}$ & $\begin{array}{l}\mathrm{T}-\mathrm{C} \\
\text { (iii) }\end{array}$ & $\begin{array}{l}\text { Treatment } \\
\text { (iv) }\end{array}$ & $\begin{array}{l}\text { Control } \\
\text { (v) }\end{array}$ & $\begin{array}{l}\mathrm{T}-\mathrm{C} \\
(\mathrm{vi})\end{array}$ & $\begin{array}{l}\text { Treatment } \\
\text { (vii) }\end{array}$ & $\begin{array}{l}\text { Control } \\
\text { (viii) }\end{array}$ & $\begin{array}{l}\mathrm{T}-\mathrm{C} \\
\text { (ix) }\end{array}$ \\
\hline \multicolumn{10}{|l|}{ Panel A: HIGH-exposure households } \\
\hline $\begin{array}{l}\text { 1. Parental aspirations before } \\
\text { the start of PROGRESA }\end{array}$ & $\begin{array}{l}11.462 \\
(0.105)\end{array}$ & $\begin{array}{c}11.663 \\
(0.13)\end{array}$ & $\begin{array}{c}-0.202 \\
(0.167)\end{array}$ & $\begin{array}{l}11.143 \\
(0.102)\end{array}$ & $\begin{array}{l}11.378 \\
(0.125)\end{array}$ & $\begin{array}{c}-0.235 \\
(0.161)\end{array}$ & $\begin{array}{l}11.368 \\
(0.104)\end{array}$ & $\begin{array}{c}11.554 \\
(0.129)\end{array}$ & $\begin{array}{c}-0.186 \\
(0.166)\end{array}$ \\
\hline $\begin{array}{l}\text { 2. Parental aspirations after } 6 \text { months of } \\
\text { the start of PROGRESA }\end{array}$ & $\begin{array}{l}13.021 \\
(0.084)\end{array}$ & $\begin{array}{l}12.782 \\
(0.111)\end{array}$ & $\begin{array}{c}0.239 \\
(0.139)\end{array}$ & $\begin{array}{l}12.923 \\
(0.093)\end{array}$ & $\begin{array}{l}12.597 \\
(0.116)\end{array}$ & $\begin{array}{c}0.326 \\
(0.149)\end{array}$ & $\begin{array}{l}13.010 \\
(0.088)\end{array}$ & $\begin{array}{l}12.832 \\
(0.113)\end{array}$ & $\begin{array}{c}0.178 \\
(0.143)\end{array}$ \\
\hline $\begin{array}{l}\text { 3. Parental aspirations after } 1 \text { year of } \\
\text { the start of PROGRESA }\end{array}$ & $\begin{array}{l}12.501 \\
(0.082)\end{array}$ & $\begin{array}{l}12.430 \\
(0.094)\end{array}$ & $\begin{array}{c}0.071 \\
(0.125)\end{array}$ & $\begin{array}{l}12.441 \\
(0.086)\end{array}$ & $\begin{array}{l}12.333 \\
(0.106)\end{array}$ & $\begin{array}{c}0.108 \\
(0.136)\end{array}$ & $\begin{array}{l}12.414 \\
(0.083)\end{array}$ & $\begin{array}{l}12.400 \\
(0.101)\end{array}$ & $\begin{array}{c}0.014 \\
(0.130)\end{array}$ \\
\hline $\begin{array}{l}\text { 4. Change in mean aspirations } \\
\text { baseline vs. } 6 \text { months }\end{array}$ & $\begin{array}{c}1.560 \\
(0.107)\end{array}$ & $\begin{array}{c}1.118 \\
(0.147)\end{array}$ & $\begin{array}{c}0.441 \\
(0.182)\end{array}$ & $\begin{array}{c}1.780 \\
(0.110)\end{array}$ & $\begin{array}{c}1.219 \\
(0.147)\end{array}$ & $\begin{array}{c}0.561 \\
(0.184)\end{array}$ & $\begin{array}{c}1.643 \\
(0.110)\end{array}$ & $\begin{array}{c}1.278 \\
(0.149)\end{array}$ & $\begin{array}{c}0.365 \\
(0.185)\end{array}$ \\
\hline $\begin{array}{l}\text { 5. Change in mean aspirations } \\
\text { baseline vs. } 1 \text { year }\end{array}$ & $\begin{array}{c}1.040 \\
(0.102)\end{array}$ & $\begin{array}{c}0.767 \\
(0.132)\end{array}$ & $\begin{array}{c}0.273 \\
(0.167)\end{array}$ & $\begin{array}{c}1.298 \\
(0.107)\end{array}$ & $\begin{array}{c}0.955 \\
(0.134)\end{array}$ & $\begin{array}{c}0.344 \\
(0.172)\end{array}$ & $\begin{array}{c}1.046 \\
(0.100)\end{array}$ & $\begin{array}{c}0.845 \\
(0.135)\end{array}$ & $\begin{array}{c}0.200 \\
(0.167)\end{array}$ \\
\hline 6. Line 4 - Line 5 & $\begin{array}{c}0.520 \\
(0.093)\end{array}$ & $\begin{array}{c}0.352 \\
(0.126)\end{array}$ & $\begin{array}{c}0.168 \\
(0.156)\end{array}$ & $\begin{array}{c}0.481 \\
(0.101)\end{array}$ & $\begin{array}{c}0.264 \\
(0.138)\end{array}$ & $\begin{array}{c}0.217 \\
(0.170)\end{array}$ & $\begin{array}{c}0.597 \\
(0.097)\end{array}$ & $\begin{array}{c}0.433 \\
(0.134)\end{array}$ & $\begin{array}{c}0.164 \\
(0.165)\end{array}$ \\
\hline \multicolumn{10}{|l|}{ Panel B: LOW-exposure households } \\
\hline $\begin{array}{l}\text { 7. Parental aspirations before } \\
\text { the start of PROGRESA }\end{array}$ & $\begin{array}{l}12.037 \\
(0.117)\end{array}$ & $\begin{array}{l}11.985 \\
(0.133)\end{array}$ & $\begin{array}{c}0.052 \\
(0.177)\end{array}$ & $\begin{array}{l}11.663 \\
(0.115)\end{array}$ & $\begin{array}{l}11.670 \\
(0.127)\end{array}$ & $\begin{array}{l}-0.007 \\
(0.171)\end{array}$ & $\begin{array}{l}11.896 \\
(0.118)\end{array}$ & $\begin{array}{l}11.886 \\
(0.129)\end{array}$ & $\begin{array}{c}0.011 \\
(0.175)\end{array}$ \\
\hline $\begin{array}{l}\text { 8. Parental aspirations after } 6 \text { months of } \\
\text { the start of PROGRESA }\end{array}$ & $\begin{array}{l}13.115 \\
(0.097)\end{array}$ & $\begin{array}{c}13.003 \\
(0.11)\end{array}$ & $\begin{array}{c}0.112 \\
(0.147)\end{array}$ & $\begin{array}{l}12.988 \\
(0.104)\end{array}$ & $\begin{array}{l}12.959 \\
(0.127)\end{array}$ & $\begin{array}{c}0.029 \\
(0.164)\end{array}$ & $\begin{array}{l}13.144 \\
(0.102)\end{array}$ & $\begin{array}{l}13.051 \\
(0.116)\end{array}$ & $\begin{array}{c}0.092 \\
(0.155)\end{array}$ \\
\hline $\begin{array}{l}\text { 9. Parental aspirations after } 1 \text { year of } \\
\text { the start of PROGRESA }\end{array}$ & $\begin{array}{l}12.669 \\
(0.098)\end{array}$ & $\begin{array}{l}12.371 \\
(0.113)\end{array}$ & $\begin{array}{l}0.298 \\
(0.15)\end{array}$ & $\begin{array}{l}12.653 \\
(0.105)\end{array}$ & $\begin{array}{l}12.264 \\
(0.130)\end{array}$ & $\begin{array}{c}0.389 \\
(0.167)\end{array}$ & $\begin{array}{l}12.662 \\
(0.104)\end{array}$ & $\begin{array}{l}12.423 \\
(0.119)\end{array}$ & $\begin{array}{c}0.240 \\
(0.158)\end{array}$ \\
\hline $\begin{array}{l}\text { 10. Change in mean aspirations } \\
\text { baseline vs. } 6 \text { months }\end{array}$ & $\begin{array}{c}1.078 \\
(0.124)\end{array}$ & $\begin{array}{c}1.018 \\
(0.157)\end{array}$ & $\begin{array}{c}0.060 \\
(0.199)\end{array}$ & $\begin{array}{c}1.325 \\
(0.133)\end{array}$ & $\begin{array}{c}1.290 \\
(0.165)\end{array}$ & $\begin{array}{c}0.036 \\
(0.212)\end{array}$ & $\begin{array}{c}1.247 \\
(0.128)\end{array}$ & $\begin{array}{c}1.166 \\
(0.167)\end{array}$ & $\begin{array}{c}0.082 \\
(0.211)\end{array}$ \\
\hline $\begin{array}{l}\text { 11. Change in mean aspirations } \\
\text { baseline vs. } 1 \text { year }\end{array}$ & $\begin{array}{c}0.632 \\
(0.127)\end{array}$ & $\begin{array}{l}0.387 \\
(0.16)\end{array}$ & $\begin{array}{c}0.246 \\
(0.204)\end{array}$ & $\begin{array}{c}0.990 \\
(0.133)\end{array}$ & $\begin{array}{c}0.594 \\
(0.170)\end{array}$ & $\begin{array}{c}0.396 \\
(0.215)\end{array}$ & $\begin{array}{c}0.766 \\
(0.134)\end{array}$ & $\begin{array}{c}0.537 \\
(0.166)\end{array}$ & $\begin{array}{c}0.229 \\
(0.213)\end{array}$ \\
\hline 12. Line 10 - Line 11 & $\begin{array}{c}0.446 \\
(0.107)\end{array}$ & $\begin{array}{l}0.632 \\
(0.14)\end{array}$ & $\begin{array}{l}-0.186 \\
(0.176)\end{array}$ & $\begin{array}{c}0.336 \\
(0.115)\end{array}$ & $\begin{array}{c}0.696 \\
(0.160)\end{array}$ & $\begin{array}{l}-0.360 \\
(0.196)\end{array}$ & $\begin{array}{c}0.481 \\
(0.124)\end{array}$ & $\begin{array}{c}0.629 \\
(0.151)\end{array}$ & $\begin{array}{l}-0.147 \\
(0.195)\end{array}$ \\
\hline \multicolumn{10}{|l|}{ Panel C: Triple difference estimates } \\
\hline $\begin{array}{l}\text { 13. Difference between HIGH- and LOW- } \\
\text { exposure HHs, baseline vs. } 6 \text { months }\end{array}$ & $\begin{array}{c}0.482 \\
(0.125)\end{array}$ & $\begin{array}{c}0.100 \\
(0.153)\end{array}$ & $\begin{array}{c}0.382 \\
(0.197)\end{array}$ & $\begin{array}{c}0.454 \\
(0.135)\end{array}$ & $\begin{array}{l}-0.071 \\
(0.173)\end{array}$ & $\begin{array}{c}0.525 \\
(0.219)\end{array}$ & $\begin{array}{c}0.395 \\
(0.132)\end{array}$ & $\begin{array}{c}0.112 \\
(0.165)\end{array}$ & $\begin{array}{c}0.283 \\
(0.211)\end{array}$ \\
\hline $\begin{array}{l}\text { 14. Difference between HIGH- and LOW- } \\
\text { exposure HHs, baseline vs. } 1 \text { year }\end{array}$ & $\begin{array}{c}0.407 \\
(0.123)\end{array}$ & $\begin{array}{c}0.380 \\
(0.151)\end{array}$ & $\begin{array}{c}0.027 \\
(0.195)\end{array}$ & $\begin{array}{c}0.309 \\
(0.128)\end{array}$ & $\begin{array}{c}0.361 \\
(0.165)\end{array}$ & $\begin{array}{l}-0.052 \\
(0.209)\end{array}$ & $\begin{array}{c}0.280 \\
(0.128)\end{array}$ & $\begin{array}{c}0.308 \\
(0.167)\end{array}$ & $\begin{array}{l}-0.029 \\
(0.210)\end{array}$ \\
\hline 15. Line 13 - Line 14 & $\begin{array}{c}0.074 \\
(0.119)\end{array}$ & $\begin{array}{l}-0.280 \\
(0.155)\end{array}$ & $\begin{array}{c}0.354 \\
(0.195)\end{array}$ & $\begin{array}{c}0.146 \\
(0.131)\end{array}$ & $\begin{array}{c}-0.432 \\
(0.185)\end{array}$ & $\begin{array}{c}0.577 \\
(0.226)\end{array}$ & $\begin{array}{c}0.116 \\
(0.134)\end{array}$ & $\begin{array}{c}-0.196 \\
(0.173)\end{array}$ & $\begin{array}{c}0.312 \\
(0.218)\end{array}$ \\
\hline
\end{tabular}

Note: Robust standard errors clustered at the village level in parenthesis. 
Table 6: Effect of Social Interactions on Average Aspirations at the Household Level After the Start of PROGRESA

\begin{tabular}{|c|c|c|c|c|c|c|c|c|c|c|c|c|}
\hline & \multicolumn{4}{|c|}{ All children } & \multicolumn{4}{|c|}{ Daughters } & \multicolumn{4}{|c|}{ Sons } \\
\hline & $(1)$ & $(2)$ & (3) & (4) & (5) & $(6)$ & $(7)$ & (8) & (9) & $(10)$ & $(11)$ & $(12)$ \\
\hline \multicolumn{13}{|l|}{ Panel A: Impact after 6 months } \\
\hline $\begin{array}{l}\text { Exposure effect } \\
\text { (Time x Treatment x Exposure) }\end{array}$ & $\begin{array}{l}0.382 * \\
(0.197)\end{array}$ & $\begin{array}{l}0.380^{*} \\
(0.198)\end{array}$ & $\begin{array}{l}0.376^{*} \\
(0.214)\end{array}$ & $\begin{array}{l}0.387^{*} \\
(0.218)\end{array}$ & $\begin{array}{l}0.525 * * \\
(0.219)\end{array}$ & $\begin{array}{l}0.523^{* *} \\
(0.219)\end{array}$ & $\begin{array}{l}0.542 * * \\
(0.233)\end{array}$ & $\begin{array}{l}0.555^{* *} \\
(0.240)\end{array}$ & $\begin{array}{c}0.283 \\
(0.211)\end{array}$ & $\begin{array}{c}0.270 \\
(0.211)\end{array}$ & $\begin{array}{c}0.256 \\
(0.229)\end{array}$ & $\begin{array}{c}0.295 \\
(0.234)\end{array}$ \\
\hline PROGRESA effect & $\begin{array}{c}0.060 \\
(0.199)\end{array}$ & $\begin{array}{c}0.062 \\
(0.200)\end{array}$ & $\begin{array}{c}0.069 \\
(0.212)\end{array}$ & $\begin{array}{c}0.041 \\
(0.215)\end{array}$ & $\begin{array}{c}0.036 \\
(0.211)\end{array}$ & $\begin{array}{c}0.035 \\
(0.212)\end{array}$ & $\begin{array}{c}0.032 \\
(0.227)\end{array}$ & $\begin{array}{c}0.010 \\
(0.233)\end{array}$ & $\begin{array}{c}0.082 \\
(0.211)\end{array}$ & $\begin{array}{c}0.099 \\
(0.210)\end{array}$ & $\begin{array}{c}0.113 \\
(0.222)\end{array}$ & $\begin{array}{c}0.064 \\
(0.227)\end{array}$ \\
\hline Parents' highest educational level in years & & $\begin{array}{l}0.179 * * * \\
(0.013)\end{array}$ & & & & $\begin{array}{l}0.179 * * * \\
(0.014)\end{array}$ & & & & $\begin{array}{c}0.175^{* * *} \\
(0.014)\end{array}$ & & \\
\hline Controls for parental characteristics ${ }^{1}$ & No & No & Yes & Yes & No & No & Yes & Yes & No & No & Yes & Yes \\
\hline Controls for household characteristics $^{2}$ & No & No & No & Yes & No & No & No & Yes & No & No & No & Yes \\
\hline Probability value for controls ${ }^{3}$ & --- & --- & 0.000 & 0.000 & --- & --- & 0.000 & 0.000 & --- & --- & 0.000 & 0.000 \\
\hline Obs. & 15,438 & 15,433 & 13,908 & 12,992 & 13,415 & 13,411 & 12,110 & 11,348 & 13,801 & 13,797 & 12,451 & 11,667 \\
\hline $\mathrm{R}^{2}$ (overall) & 0.047 & 0.069 & 0.084 & 0.087 & 0.058 & 0.080 & 0.094 & 0.098 & 0.053 & 0.074 & 0.087 & 0.090 \\
\hline \multicolumn{13}{|l|}{ Panel B: Impact after 1 year } \\
\hline $\begin{array}{l}\text { Exposure effect } \\
\text { (Time x Treatment x Exposure) }\end{array}$ & $\begin{array}{c}0.027 \\
(0.195)\end{array}$ & $\begin{array}{c}0.022 \\
(0.195)\end{array}$ & $\begin{array}{c}0.067 \\
(0.202)\end{array}$ & $\begin{array}{c}0.059 \\
(0.207)\end{array}$ & $\begin{array}{l}-0.052 \\
(0.209)\end{array}$ & $\begin{array}{l}-0.068 \\
(0.210)\end{array}$ & $\begin{array}{c}0.012 \\
(0.218)\end{array}$ & $\begin{array}{c}0.051 \\
(0.225)\end{array}$ & $\begin{array}{l}-0.029 \\
(0.210)\end{array}$ & $\begin{array}{l}-0.039 \\
(0.210)\end{array}$ & $\begin{array}{c}0.031 \\
(0.217)\end{array}$ & $\begin{array}{c}0.015 \\
(0.227)\end{array}$ \\
\hline PROGRESA effect & $\begin{array}{c}0.246 \\
(0.204)\end{array}$ & $\begin{array}{c}0.250 \\
(0.152)\end{array}$ & $\begin{array}{c}0.209 \\
(0.210)\end{array}$ & $\begin{array}{c}0.200 \\
(0.216)\end{array}$ & $\begin{array}{l}0.396 * \\
(0.215)\end{array}$ & $\begin{array}{l}0.407 * \\
(0.217)\end{array}$ & $\begin{array}{c}0.333 \\
(0.224)\end{array}$ & $\begin{array}{c}0.319 \\
(0.233)\end{array}$ & $\begin{array}{c}0.229 \\
(0.213)\end{array}$ & $\begin{array}{c}0.235 \\
(0.213)\end{array}$ & $\begin{array}{c}0.159 \\
(0.219)\end{array}$ & $\begin{array}{c}0.135 \\
(0.225)\end{array}$ \\
\hline Parents' highest educational level in years & & $\begin{array}{c}0.168 * * * \\
(0.014)\end{array}$ & & & & $\begin{array}{c}0.167 * * * \\
(0.015)\end{array}$ & & & & $\begin{array}{c}0.168 * * * \\
(0.015)\end{array}$ & & \\
\hline Controls for parental characteristics ${ }^{1}$ & No & No & Yes & Yes & No & No & Yes & Yes & No & No & Yes & Yes \\
\hline Controls for household characteristics ${ }^{2}$ & No & No & No & Yes & No & No & No & Yes & No & No & No & Yes \\
\hline Probability value for controls ${ }^{1}$ & --- & --- & 0.000 & 0.000 & --- & --- & 0.000 & 0.000 & --- & --- & 0.000 & 0.000 \\
\hline Obs. & 15,137 & 15,131 & 13,682 & 12,725 & 13,324 & 13,319 & 12,072 & 11,276 & 13,641 & 13,637 & 12,337 & 11,516 \\
\hline $\mathrm{R}^{2}$ (overall) & 0.022 & 0.043 & 0.060 & 0.062 & 0.033 & 0.053 & 0.068 & 0.071 & 0.024 & 0.044 & 0.058 & 0.060 \\
\hline
\end{tabular}

Note: Robust standard errors clustered at the village level in parenthesis. Each individual coefficient is statistically significant at the $* 10 \%$, $* * 5 \%$, or $* * * 1 \%$ level.

${ }^{1}$ Head's age, his educational level, whether he is literate, whether he is indigenous, the spouse's age, her educational level, whether she is literate, and whether she is indigenous.

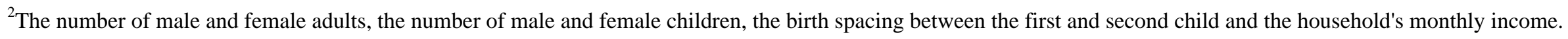

${ }^{3}$ Probability value of joint $\mathrm{F}$ test for exclusion of all control variables. 
Table 7: Average Aspirations per Household Before and After the Start of PROGRESA

(at least COLLEGE)

\begin{tabular}{|c|c|c|c|c|c|c|c|c|c|}
\hline & \multicolumn{3}{|c|}{ All children } & \multicolumn{3}{|c|}{ Daughters } & \multicolumn{3}{|c|}{ Sons } \\
\hline & $\begin{array}{l}\text { Treatment } \\
\text { (i) }\end{array}$ & $\begin{array}{l}\text { Control } \\
\text { (ii) }\end{array}$ & $\begin{array}{l}\mathrm{T}-\mathrm{C} \\
\text { (iii) }\end{array}$ & $\begin{array}{l}\text { Treatment } \\
\text { (iv) }\end{array}$ & $\begin{array}{l}\text { Control } \\
\text { (v) }\end{array}$ & $\begin{array}{l}\mathrm{T}-\mathrm{C} \\
\text { (vi) }\end{array}$ & $\begin{array}{l}\text { Treatment } \\
\text { (vii) }\end{array}$ & $\begin{array}{l}\text { Control } \\
\text { (viii) }\end{array}$ & $\begin{array}{l}\mathrm{T}-\mathrm{C} \\
\text { (ix) }\end{array}$ \\
\hline \multirow{4}{*}{$\begin{array}{l}\text { 1. Parental aspirations before } \\
\text { the start of PROGRESA } \\
\text { 2. Parental aspirations after } 6 \text { months of } \\
\text { the start of PROGRESA }\end{array}$} & 0.264 & 0.281 & -0.017 & 0.228 & 0.248 & -0.020 & 0.257 & 0.273 & -0.016 \\
\hline & $(0.012)$ & $(0.015)$ & $(0.02)$ & $(0.011)$ & $(0.015)$ & $(0.018)$ & $(0.012)$ & $(0.015)$ & $(0.019)$ \\
\hline & 0.421 & 0.398 & 0.023 & 0.397 & 0.371 & 0.026 & 0.423 & 0.406 & 0.017 \\
\hline & $(0.011)$ & $(0.016)$ & $(0.02)$ & $(0.013)$ & $(0.016)$ & $(0.021)$ & $(0.012)$ & $(0.016)$ & $(0.020)$ \\
\hline \multirow{2}{*}{$\begin{array}{l}\text { 3. Parental aspirations after } 1 \text { year of } \\
\text { the start of PROGRESA }\end{array}$} & 0.313 & 0.280 & 0.033 & 0.306 & 0.269 & 0.037 & 0.306 & 0.284 & 0.022 \\
\hline & $(0.012)$ & $(0.015)$ & $(0.019)$ & $(0.013)$ & $(0.016)$ & $(0.020)$ & $(0.012)$ & $(0.016)$ & $(0.020)$ \\
\hline \multirow{4}{*}{$\begin{array}{l}\text { 4. Change in mean aspirations } \\
\text { baseline vs. } 6 \text { months } \\
\text { 5. Change in mean aspirations } \\
\text { baseline vs. } 1 \text { year }\end{array}$} & 0.157 & 0.117 & 0.040 & 0.169 & 0.123 & 0.046 & 0.166 & 0.133 & 0.033 \\
\hline & $(0.014)$ & $(0.019)$ & $(0.024)$ & $(0.015)$ & $(0.019)$ & $(0.024)$ & $(0.014)$ & $(0.02)$ & $(0.024)$ \\
\hline & 0.049 & -0.001 & 0.050 & 0.078 & 0.021 & 0.057 & 0.049 & 0.011 & 0.038 \\
\hline & $(0.015)$ & $(0.019)$ & $(0.024)$ & $(0.016)$ & $(0.019)$ & $(0.024)$ & $(0.015)$ & $(0.020)$ & $(0.025)$ \\
\hline
\end{tabular}

Note: Robust standard errors clustered at the village level in parenthesis. 
Table 8: Average Aspirations per Household Before and After the Start of PROGRESA by Type of Household

(at least COLLEGE)

\begin{tabular}{|c|c|c|c|c|c|c|c|c|c|}
\hline & \multicolumn{3}{|c|}{ All children } & \multicolumn{3}{|c|}{ Daughters } & \multicolumn{3}{|c|}{ Sons } \\
\hline & $\begin{array}{l}\text { Treatment } \\
\text { (i) }\end{array}$ & $\begin{array}{l}\text { Control } \\
\text { (ii) }\end{array}$ & $\begin{array}{l}\mathrm{T}-\mathrm{C} \\
\text { (iii) }\end{array}$ & $\begin{array}{l}\text { Treatment } \\
\text { (iv) }\end{array}$ & $\begin{array}{l}\text { Control } \\
\text { (v) }\end{array}$ & $\begin{array}{l}\mathrm{T}-\mathrm{C} \\
\text { (vi) }\end{array}$ & $\begin{array}{l}\text { Treatment } \\
\text { (vii) }\end{array}$ & $\begin{array}{l}\text { Control } \\
\text { (viii) }\end{array}$ & $\begin{array}{l}\mathrm{T}-\mathrm{C} \\
\text { (ix) }\end{array}$ \\
\hline \multicolumn{10}{|l|}{ Panel A: HIGH-exposure households } \\
\hline $\begin{array}{l}\text { 1. Parental aspirations before } \\
\text { the start of PROGRESA }\end{array}$ & $\begin{array}{c}0.242 \\
(0.012)\end{array}$ & $\begin{array}{c}0.273 \\
(0.017)\end{array}$ & $\begin{array}{l}-0.031 \\
(0.021)\end{array}$ & $\begin{array}{c}0.209 \\
(0.012)\end{array}$ & $\begin{array}{c}0.242 \\
(0.016)\end{array}$ & $\begin{array}{l}-0.033 \\
(0.020)\end{array}$ & $\begin{array}{c}0.237 \\
(0.012)\end{array}$ & $\begin{array}{c}0.266 \\
(0.017)\end{array}$ & $\begin{array}{l}-0.030 \\
(0.021)\end{array}$ \\
\hline $\begin{array}{l}\text { 2. Parental aspirations after } 6 \text { months of } \\
\text { the start of PROGRESA }\end{array}$ & $\begin{array}{c}0.418 \\
(0.013)\end{array}$ & $\begin{array}{c}0.385 \\
(0.018)\end{array}$ & $\begin{array}{c}0.033 \\
(0.022)\end{array}$ & $\begin{array}{c}0.394 \\
(0.014)\end{array}$ & $\begin{array}{c}0.352 \\
(0.018)\end{array}$ & $\begin{array}{c}0.042 \\
(0.023)\end{array}$ & $\begin{array}{c}0.415 \\
(0.013)\end{array}$ & $\begin{array}{c}0.392 \\
(0.019)\end{array}$ & $\begin{array}{c}0.023 \\
(0.023)\end{array}$ \\
\hline $\begin{array}{l}\text { 3. Parental aspirations after } 1 \text { year of } \\
\text { the start of PROGRESA }\end{array}$ & $\begin{array}{c}0.306 \\
(0.013)\end{array}$ & $\begin{array}{c}0.283 \\
(0.017)\end{array}$ & $\begin{array}{c}0.024 \\
(0.021)\end{array}$ & $\begin{array}{c}0.301 \\
(0.014)\end{array}$ & $\begin{array}{c}0.272 \\
(0.018)\end{array}$ & $\begin{array}{c}0.029 \\
(0.023)\end{array}$ & $\begin{array}{c}0.295 \\
(0.012)\end{array}$ & $\begin{array}{c}0.283 \\
(0.018)\end{array}$ & $\begin{array}{c}0.013 \\
(0.022)\end{array}$ \\
\hline $\begin{array}{l}\text { 4. Change in mean aspirations } \\
\text { baseline vs. } 6 \text { months }\end{array}$ & $\begin{array}{c}0.176 \\
(0.016)\end{array}$ & $\begin{array}{c}0.112 \\
(0.022)\end{array}$ & $\begin{array}{c}0.064 \\
(0.027)\end{array}$ & $\begin{array}{c}0.184 \\
(0.017)\end{array}$ & $\begin{array}{c}0.110 \\
(0.021)\end{array}$ & $\begin{array}{c}0.075 \\
(0.027)\end{array}$ & $\begin{array}{c}0.179 \\
(0.016)\end{array}$ & $\begin{array}{c}0.126 \\
(0.022)\end{array}$ & $\begin{array}{c}0.053 \\
(0.027)\end{array}$ \\
\hline $\begin{array}{l}\text { 5. Change in mean aspirations } \\
\text { baseline vs. } 1 \text { year }\end{array}$ & $\begin{array}{c}0.065 \\
(0.016)\end{array}$ & $\begin{array}{c}0.010 \\
(0.021)\end{array}$ & $\begin{array}{c}0.055 \\
(0.027)\end{array}$ & $\begin{array}{c}0.091 \\
(0.017)\end{array}$ & $\begin{array}{c}0.030 \\
(0.021)\end{array}$ & $\begin{array}{c}0.061 \\
(0.027)\end{array}$ & $\begin{array}{c}0.058 \\
(0.016)\end{array}$ & $\begin{array}{c}0.016 \\
(0.023)\end{array}$ & $\begin{array}{c}0.042 \\
(0.028)\end{array}$ \\
\hline 6. Line 4 - Line 5 & $\begin{array}{c}0.111 \\
(0.015)\end{array}$ & $\begin{array}{c}0.102 \\
(0.023)\end{array}$ & $\begin{array}{c}0.009 \\
(0.028)\end{array}$ & $\begin{array}{c}0.093 \\
(0.017)\end{array}$ & $\begin{array}{c}0.080 \\
(0.024)\end{array}$ & $\begin{array}{c}0.014 \\
(0.029)\end{array}$ & $\begin{array}{c}0.120 \\
(0.016)\end{array}$ & $\begin{array}{c}0.110 \\
(0.026)\end{array}$ & $\begin{array}{c}0.011 \\
(0.030)\end{array}$ \\
\hline \multicolumn{10}{|l|}{ Panel B: LOW-exposure households } \\
\hline $\begin{array}{l}\text { 7. Parental aspirations before } \\
\text { the start of PROGRESA }\end{array}$ & $\begin{array}{c}0.306 \\
(0.016)\end{array}$ & $\begin{array}{c}0.295 \\
(0.018)\end{array}$ & $\begin{array}{c}0.011 \\
(0.024)\end{array}$ & $\begin{array}{c}0.263 \\
(0.015)\end{array}$ & $\begin{array}{c}0.259 \\
(0.018)\end{array}$ & $\begin{array}{c}0.004 \\
(0.023)\end{array}$ & $\begin{array}{c}0.295 \\
(0.016)\end{array}$ & $\begin{array}{c}0.285 \\
(0.018)\end{array}$ & $\begin{array}{c}0.010 \\
(0.024)\end{array}$ \\
\hline $\begin{array}{l}\text { 8. Parental aspirations after } 6 \text { months of } \\
\text { the start of PROGRESA }\end{array}$ & $\begin{array}{c}0.427 \\
(0.015)\end{array}$ & $\begin{array}{c}0.421 \\
(0.018)\end{array}$ & $\begin{array}{c}0.007 \\
(0.024)\end{array}$ & $\begin{array}{c}0.402 \\
(0.016)\end{array}$ & $\begin{array}{c}0.408 \\
(0.021)\end{array}$ & $\begin{array}{l}-0.006 \\
(0.027)\end{array}$ & $\begin{array}{c}0.437 \\
(0.016)\end{array}$ & $\begin{array}{c}0.430 \\
(0.018)\end{array}$ & $\begin{array}{c}0.007 \\
(0.024)\end{array}$ \\
\hline $\begin{array}{l}\text { 9. Parental aspirations after } 1 \text { year of } \\
\text { the start of PROGRESA }\end{array}$ & $\begin{array}{c}0.325 \\
(0.016)\end{array}$ & $\begin{array}{c}0.275 \\
(0.018)\end{array}$ & $\begin{array}{c}0.050 \\
(0.024)\end{array}$ & $\begin{array}{c}0.318 \\
(0.018)\end{array}$ & $\begin{array}{l}0.264 \\
(0.02)\end{array}$ & $\begin{array}{c}0.055 \\
(0.027)\end{array}$ & $\begin{array}{c}0.328 \\
(0.018)\end{array}$ & $\begin{array}{c}0.287 \\
(0.020)\end{array}$ & $\begin{array}{c}0.040 \\
(0.026)\end{array}$ \\
\hline $\begin{array}{l}\text { 10. Change in mean aspirations } \\
\text { baseline vs. } 6 \text { months }\end{array}$ & $\begin{array}{c}0.122 \\
(0.019)\end{array}$ & $\begin{array}{c}0.126 \\
(0.025)\end{array}$ & $\begin{array}{l}-0.005 \\
(0.031)\end{array}$ & $\begin{array}{l}0.139 \\
(0.02)\end{array}$ & $\begin{array}{c}0.149 \\
(0.027)\end{array}$ & $\begin{array}{l}-0.009 \\
(0.033)\end{array}$ & $\begin{array}{c}0.142 \\
(0.020)\end{array}$ & $\begin{array}{c}0.145 \\
(0.026)\end{array}$ & $\begin{array}{l}-0.003 \\
(0.033)\end{array}$ \\
\hline $\begin{array}{l}\text { 11. Change in mean aspirations } \\
\text { baseline vs. } 1 \text { year }\end{array}$ & $\begin{array}{l}0.019 \\
(0.02)\end{array}$ & $\begin{array}{l}-0.020 \\
(0.023)\end{array}$ & $\begin{array}{c}0.039 \\
(0.031)\end{array}$ & $\begin{array}{c}0.056 \\
(0.021)\end{array}$ & $\begin{array}{c}0.005 \\
(0.026)\end{array}$ & $\begin{array}{c}0.051 \\
(0.033)\end{array}$ & $\begin{array}{c}0.033 \\
(0.022)\end{array}$ & $\begin{array}{c}0.002 \\
(0.025)\end{array}$ & $\begin{array}{c}0.031 \\
(0.033)\end{array}$ \\
\hline 12. Line 10 - Line 11 & $\begin{array}{c}0.102 \\
(0.019)\end{array}$ & $\begin{array}{c}0.146 \\
(0.023)\end{array}$ & $\begin{array}{r}-0.044 \\
(0.03)\end{array}$ & $\begin{array}{c}0.084 \\
(0.022)\end{array}$ & $\begin{array}{c}0.144 \\
(0.025)\end{array}$ & $\begin{array}{l}-0.060 \\
(0.033)\end{array}$ & $\begin{array}{c}0.109 \\
(0.022)\end{array}$ & $\begin{array}{c}0.143 \\
(0.025)\end{array}$ & $\begin{array}{l}-0.034 \\
(0.033)\end{array}$ \\
\hline \multicolumn{10}{|l|}{ Panel C: Triple difference estimates } \\
\hline $\begin{array}{l}\text { 13. Difference between HIGH- and LOW- } \\
\text { exposure HHs, baseline vs. } 6 \text { months }\end{array}$ & $\begin{array}{l}0.054 \\
(0.02)\end{array}$ & $\begin{array}{l}-0.014 \\
(0.026)\end{array}$ & $\begin{array}{c}0.069 \\
(0.033)\end{array}$ & $\begin{array}{c}0.045 \\
(0.021)\end{array}$ & $\begin{array}{l}-0.039 \\
(0.029)\end{array}$ & $\begin{array}{c}0.084 \\
(0.035)\end{array}$ & $\begin{array}{c}0.037 \\
(0.021)\end{array}$ & $\begin{array}{l}-0.019 \\
(0.028)\end{array}$ & $\begin{array}{c}0.056 \\
(0.035)\end{array}$ \\
\hline $\begin{array}{l}\text { 14. Difference between HIGH- and LOW- } \\
\text { exposure HHs, baseline vs. } 1 \text { year }\end{array}$ & $\begin{array}{l}0.045 \\
(0.02)\end{array}$ & $\begin{array}{c}0.030 \\
(0.024)\end{array}$ & $\begin{array}{c}0.016 \\
(0.031)\end{array}$ & $\begin{array}{c}0.036 \\
(0.021)\end{array}$ & $\begin{array}{c}0.025 \\
(0.028)\end{array}$ & $\begin{array}{c}0.010 \\
(0.035)\end{array}$ & $\begin{array}{c}0.025 \\
(0.021)\end{array}$ & $\begin{array}{c}0.014 \\
(0.026)\end{array}$ & $\begin{array}{c}0.011 \\
(0.033)\end{array}$ \\
\hline 15. Line 13 - Line 14 & $\begin{array}{l}0.009 \\
(0.02)\end{array}$ & $\begin{array}{c}-0.044 \\
(0.025)\end{array}$ & $\begin{array}{c}0.053 \\
(0.032)\end{array}$ & $\begin{array}{c}0.009 \\
(0.024)\end{array}$ & $\begin{array}{c}-0.064 \\
(0.03)\end{array}$ & $\begin{array}{c}0.074 \\
(0.038)\end{array}$ & $\begin{array}{c}0.011 \\
(0.022)\end{array}$ & $\begin{array}{c}-0.033 \\
(0.030)\end{array}$ & $\begin{array}{c}0.045 \\
(0.037)\end{array}$ \\
\hline
\end{tabular}

Note: Robust standard errors clustered at the village level in parenthesis. 
Table 9: Age effect

\begin{tabular}{|c|c|c|c|c|c|c|c|c|c|c|c|c|}
\hline & \multicolumn{4}{|c|}{ All children } & \multicolumn{4}{|c|}{ Daughters } & \multicolumn{4}{|c|}{ Sons } \\
\hline & $(1)$ & $(2)$ & (3) & (4) & (5) & $(6)$ & $(7)$ & $(8)$ & $(9)$ & $(10)$ & $(11)$ & (12) \\
\hline \multicolumn{13}{|l|}{ Panel A: Impact after 6 months } \\
\hline $\begin{array}{l}\text { Exposure effect } \\
\text { (Time x Treatment x Exposure) }\end{array}$ & $\begin{array}{l}0.382 * \\
(0.197)\end{array}$ & $\begin{array}{l}0.361 * \\
(0.215)\end{array}$ & $\begin{array}{l}0.400 * \\
(0.232)\end{array}$ & $\begin{array}{l}0.399 * \\
(0.236)\end{array}$ & $\begin{array}{c}0.525^{* *} \\
(0.219)\end{array}$ & $\begin{array}{c}0.504 * * \\
(0.233)\end{array}$ & $\begin{array}{c}0.562 * * \\
(0.247)\end{array}$ & $\begin{array}{c}0.582 * * \\
(0.256)\end{array}$ & $\begin{array}{c}0.283 \\
(0.211)\end{array}$ & $\begin{array}{c}0.261 \\
(0.232)\end{array}$ & $\begin{array}{c}0.272 \\
(0.250)\end{array}$ & $\begin{array}{c}0.252 \\
(0.256)\end{array}$ \\
\hline $\begin{array}{l}\text { Age effect } \\
\text { (Time x Treatment x Age youngest child }\end{array}$ & & $\begin{array}{l}-0.004 \\
(0.017)\end{array}$ & $\begin{array}{c}0.005 \\
(0.018)\end{array}$ & $\begin{array}{c}0.002 \\
(0.019)\end{array}$ & & $\begin{array}{l}-0.005 \\
(0.021)\end{array}$ & $\begin{array}{c}0.005 \\
(0.022)\end{array}$ & $\begin{array}{c}0.005 \\
(0.023)\end{array}$ & & $\begin{array}{l}-0.005 \\
(0.019)\end{array}$ & $\begin{array}{c}0.004 \\
(0.020)\end{array}$ & $\begin{array}{l}-0.008 \\
(0.021)\end{array}$ \\
\hline PROGRESA effect & $\begin{array}{c}0.060 \\
(0.199)\end{array}$ & $\begin{array}{c}0.088 \\
(0.230)\end{array}$ & $\begin{array}{c}0.035 \\
(0.245)\end{array}$ & $\begin{array}{c}0.024 \\
(0.252)\end{array}$ & $\begin{array}{c}0.036 \\
(0.211)\end{array}$ & $\begin{array}{c}0.067 \\
(0.243)\end{array}$ & $\begin{array}{c}0.002 \\
(0.260)\end{array}$ & $\begin{array}{l}-0.028 \\
(0.272)\end{array}$ & $\begin{array}{c}0.082 \\
(0.211)\end{array}$ & $\begin{array}{c}0.113 \\
(0.254)\end{array}$ & $\begin{array}{c}0.091 \\
(0.267)\end{array}$ & $\begin{array}{c}0.123 \\
(0.274)\end{array}$ \\
\hline Controls for parental characteristics ${ }^{1}$ & No & No & Yes & Yes & No & No & Yes & Yes & No & No & Yes & Yes \\
\hline Controls for household characteristics ${ }^{2}$ & No & No & No & Yes & No & No & No & Yes & No & No & No & Yes \\
\hline Probability value for controls ${ }^{3}$ & --- & --- & 0.000 & 0.000 & --- & --- & 0.000 & 0.000 & --- & --- & 0.000 & 0.000 \\
\hline Obs. & 15,438 & 15,404 & 13,887 & 12,992 & 13,415 & 13,382 & 12,090 & 11,348 & 13,801 & 13,768 & 12,430 & 11,667 \\
\hline $\mathrm{R}^{2}$ (overall) & 0.047 & 0.047 & 0.084 & 0.087 & 0.058 & 0.058 & 0.094 & 0.098 & 0.053 & 0.053 & 0.087 & 0.090 \\
\hline \multicolumn{13}{|l|}{ Panel B: Impact after 1 year } \\
\hline $\begin{array}{l}\text { Exposure effect } \\
\text { (Time x Treatment x Exposure) }\end{array}$ & $\begin{array}{c}0.027 \\
(0.195)\end{array}$ & $\begin{array}{c}0.015 \\
(0.204)\end{array}$ & $\begin{array}{c}0.034 \\
(0.210)\end{array}$ & $\begin{array}{c}0.025 \\
(0.217)\end{array}$ & $\begin{array}{l}-0.052 \\
(0.209)\end{array}$ & $\begin{array}{l}-0.067 \\
(0.217)\end{array}$ & $\begin{array}{l}-0.012 \\
(0.224)\end{array}$ & $\begin{array}{c}0.012 \\
(0.235)\end{array}$ & $\begin{array}{l}-0.029 \\
(0.210)\end{array}$ & $\begin{array}{l}-0.041 \\
(0.221)\end{array}$ & $\begin{array}{l}-0.006 \\
(0.228)\end{array}$ & $\begin{array}{l}-0.036 \\
(0.239)\end{array}$ \\
\hline $\begin{array}{l}\text { Age effect } \\
\text { (Time x Treatment x Age youngest child }\end{array}$ & & $\begin{array}{l}-0.004 \\
(0.014)\end{array}$ & $\begin{array}{l}-0.006 \\
(0.014)\end{array}$ & $\begin{array}{l}-0.008 \\
(0.015)\end{array}$ & & $\begin{array}{l}-0.005 \\
(0.016)\end{array}$ & $\begin{array}{l}-0.004 \\
(0.017)\end{array}$ & $\begin{array}{l}-0.009 \\
(0.019)\end{array}$ & & $\begin{array}{l}-0.004 \\
(0.015)\end{array}$ & $\begin{array}{l}-0.007 \\
(0.015)\end{array}$ & $\begin{array}{l}-0.012 \\
(0.017)\end{array}$ \\
\hline PROGRESA effect & $\begin{array}{c}0.246 \\
(0.204)\end{array}$ & $\begin{array}{c}0.265 \\
(0.226)\end{array}$ & $\begin{array}{c}0.253 \\
(0.232)\end{array}$ & $\begin{array}{c}0.248 \\
(0.240)\end{array}$ & $\begin{array}{l}0.396 * \\
(0.215)\end{array}$ & $\begin{array}{l}0.421^{*} \\
(0.234)\end{array}$ & $\begin{array}{c}0.365 \\
(0.244)\end{array}$ & $\begin{array}{c}0.376 \\
(0.260)\end{array}$ & $\begin{array}{c}0.229 \\
(0.213)\end{array}$ & $\begin{array}{c}0.249 \\
(0.238)\end{array}$ & $\begin{array}{c}0.209 \\
(0.243)\end{array}$ & $\begin{array}{c}0.210 \\
(0.253)\end{array}$ \\
\hline Controls for parental characteristics ${ }^{1}$ & No & No & Yes & Yes & No & No & Yes & Yes & No & No & Yes & Yes \\
\hline Controls for household characteristics ${ }^{2}$ & No & No & No & Yes & No & No & No & Yes & No & No & No & Yes \\
\hline Probability value for controls ${ }^{3}$ & --- & --- & 0.000 & 0.000 & --- & --- & 0.000 & 0.000 & --- & --- & 0.000 & 0.000 \\
\hline Obs. & 15,137 & 15,103 & 13,661 & 12,725 & 13,324 & 13,291 & 12,052 & 11,276 & 13,641 & 13,608 & 12,316 & 11,516 \\
\hline $\mathrm{R}^{2}$ (overall) & 0.022 & 0.022 & 0.060 & 0.062 & 0.033 & 0.033 & 0.068 & 0.071 & 0.024 & 0.024 & 0.058 & 0.061 \\
\hline
\end{tabular}

Note: Robust standard errors clustered at the village level in parenthesis. Each individual coefficient is statistically significant at the *10\%, **5\%, or ***1\% level.

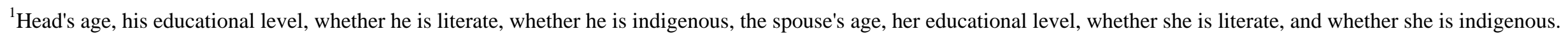

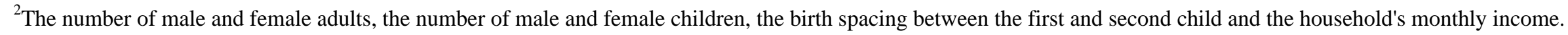

${ }^{3}$ Probability value of joint $\mathrm{F}$ test for exclusion of all control variables. 
Table 10: Effect of Children's Health on Parental Aspirations at the Household Level in Round 2

\begin{tabular}{|c|c|c|c|c|c|c|c|c|c|c|c|c|}
\hline & \multicolumn{6}{|c|}{$\begin{array}{l}\text { At least one child ill at most } 3 \text { days } \\
\text { during the previous month }\end{array}$} & \multicolumn{6}{|c|}{$\begin{array}{c}\text { At least one child ill at least } 20 \text { days } \\
\text { during the previous month }\end{array}$} \\
\hline & \multicolumn{2}{|c|}{ All children } & \multicolumn{2}{|c|}{ Daughters } & \multicolumn{2}{|c|}{ Sons } & \multicolumn{2}{|c|}{ All Children } & \multicolumn{2}{|c|}{ Daughters } & \multicolumn{2}{|c|}{ Sons } \\
\hline & $(1)$ & $(2)$ & $(3)$ & (4) & $(5)$ & (6) & $(7)$ & (8) & $(9)$ & $(10)$ & $(11)$ & (12) \\
\hline At least one child ill & $\begin{array}{c}0.189 \\
(0.239)\end{array}$ & $\begin{array}{c}0.087 \\
(0.257)\end{array}$ & $\begin{array}{c}0.177 \\
(0.284)\end{array}$ & $\begin{array}{c}0.034 \\
(0.327)\end{array}$ & $\begin{array}{c}0.021 \\
(0.279)\end{array}$ & $\begin{array}{l}-0.075 \\
(0.293)\end{array}$ & $\begin{array}{c}0.750 \\
(0.480)\end{array}$ & $\begin{array}{c}0.789 \\
(0.517)\end{array}$ & $\begin{array}{c}0.609 \\
(0.595)\end{array}$ & $\begin{array}{c}0.575 \\
(0.684)\end{array}$ & $\begin{array}{c}0.723 \\
(0.524)\end{array}$ & $\begin{array}{c}0.552 \\
(0.579)\end{array}$ \\
\hline Controls for parental characteristics ${ }^{1}$ & No & Yes & No & Yes & No & Yes & No & Yes & No & Yes & No & Yes \\
\hline Controls for household characteristics ${ }^{2}$ & No & Yes & No & Yes & No & Yes & No & Yes & No & Yes & No & Yes \\
\hline Probability value for controls ${ }^{3}$ & --- & 0.000 & --- & 0.000 & --- & 0.000 & --- & 0.000 & --- & 0.000 & --- & 0.000 \\
\hline Obs. & 2,722 & 2,305 & 2,011 & 1,720 & 2,093 & 1,807 & 2,722 & 2,305 & 2,011 & 1,720 & 2,093 & 1,807 \\
\hline $\mathrm{R}^{2}$ (overall) & 0.000 & 0.043 & 0.000 & 0.038 & 0.000 & 0.045 & 0.001 & 0.043 & 0.001 & 0.038 & 0.001 & 0.045 \\
\hline
\end{tabular}

Note: Robust standard errors clustered at the village level in parenthesis. Each individual coefficient is statistically significant at the *10\%, **5\%, or ***1\% level.

${ }^{1}$ Head's age, his educational level, whether he is literate, whether he is indigenous, the spouse's age, her educational level, whether she is literate, and whether she is indigenous.

${ }^{2}$ The number of male and female adults, the number of male and female children, the birth spacing between the first and second child and the household's monthly income.

${ }^{3}$ Probability value of joint $\mathrm{F}$ test for exclusion of all control variables. 
Table 11: Average Aspirations per Non-Eligible Household Before and After the Start of PROGRESA by Type of Household

\begin{tabular}{|c|c|c|c|c|c|c|c|c|c|}
\hline & \multicolumn{3}{|c|}{ All children } & \multicolumn{3}{|c|}{ Daughters } & \multicolumn{3}{|c|}{ Sons } \\
\hline & $\begin{array}{l}\text { Treatment } \\
\text { (i) }\end{array}$ & $\begin{array}{l}\text { Control } \\
\text { (ii) }\end{array}$ & $\begin{array}{l}\mathrm{T}-\mathrm{C} \\
\text { (iii) }\end{array}$ & $\begin{array}{l}\text { Treatment } \\
\text { (iv) }\end{array}$ & $\begin{array}{l}\text { Control } \\
\text { (v) }\end{array}$ & $\begin{array}{l}\mathrm{T}-\mathrm{C} \\
\text { (vi) }\end{array}$ & $\begin{array}{l}\text { Treatment } \\
\text { (vii) }\end{array}$ & $\begin{array}{l}\text { Control } \\
\text { (viii) }\end{array}$ & $\begin{array}{l}\text { T - C } \\
\text { (ix) }\end{array}$ \\
\hline \multicolumn{10}{|l|}{ Panel A: HIGH-exposure households } \\
\hline $\begin{array}{l}\text { 1. Parental aspirations before } \\
\text { the start of PROGRESA }\end{array}$ & $\begin{array}{l}12.658 \\
(0.132)\end{array}$ & $\begin{array}{l}12.510 \\
(0.16)\end{array}$ & $\begin{array}{c}0.148 \\
(0.208)\end{array}$ & $\begin{array}{l}12.194 \\
(0.129)\end{array}$ & $\begin{array}{l}12.123 \\
(0.158)\end{array}$ & $\begin{array}{c}0.071 \\
(0.204)\end{array}$ & $\begin{array}{l}12.513 \\
(0.135)\end{array}$ & $\begin{array}{l}12.358 \\
(0.162)\end{array}$ & $\begin{array}{c}0.155 \\
(0.210)\end{array}$ \\
\hline $\begin{array}{l}\text { 2. Parental aspirations after } 6 \text { months of } \\
\text { the start of PROGRESA }\end{array}$ & $\begin{array}{l}13.549 \\
(0.111)\end{array}$ & $\begin{array}{l}13.400 \\
(0.13)\end{array}$ & $\begin{array}{c}0.149 \\
(0.171)\end{array}$ & $\begin{array}{l}13.355 \\
(0.133)\end{array}$ & $\begin{array}{l}13.147 \\
(0.157)\end{array}$ & $\begin{array}{c}0.208 \\
(0.206)\end{array}$ & $\begin{array}{l}13.530 \\
(0.132)\end{array}$ & $\begin{array}{l}13.421 \\
(0.153)\end{array}$ & $\begin{array}{c}0.109 \\
(0.202)\end{array}$ \\
\hline $\begin{array}{l}\text { 3. Parental aspirations after } 1 \text { year of } \\
\text { the start of PROGRESA }\end{array}$ & $\begin{array}{l}13.146 \\
(0.106)\end{array}$ & $\begin{array}{l}13.097 \\
(0.133)\end{array}$ & $\begin{array}{l}0.049 \\
(0.17)\end{array}$ & $\begin{array}{l}13.036 \\
(0.120)\end{array}$ & $\begin{array}{l}12.952 \\
(0.151)\end{array}$ & $\begin{array}{c}0.084 \\
(0.193)\end{array}$ & $\begin{array}{l}13.088 \\
(0.131)\end{array}$ & $\begin{array}{l}13.046 \\
(0.160)\end{array}$ & $\begin{array}{c}0.042 \\
(0.206)\end{array}$ \\
\hline $\begin{array}{l}\text { 4. Change in mean aspirations } \\
\text { baseline vs. } 6 \text { months }\end{array}$ & $\begin{array}{c}0.891 \\
(0.158)\end{array}$ & $\begin{array}{c}0.890 \\
(0.199)\end{array}$ & $\begin{array}{c}0.001 \\
(0.254)\end{array}$ & $\begin{array}{c}1.161 \\
(0.172)\end{array}$ & $\begin{array}{c}1.024 \\
(0.210)\end{array}$ & $\begin{array}{c}0.137 \\
(0.271)\end{array}$ & $\begin{array}{c}1.017 \\
(0.175)\end{array}$ & $\begin{array}{c}1.063 \\
(0.235)\end{array}$ & $\begin{array}{l}-0.046 \\
(0.293)\end{array}$ \\
\hline $\begin{array}{l}\text { 5. Change in mean aspirations } \\
\text { baseline vs. } 1 \text { year }\end{array}$ & $\begin{array}{c}0.488 \\
(0.147)\end{array}$ & $\begin{array}{c}0.587 \\
(0.193)\end{array}$ & $\begin{array}{l}-0.099 \\
(0.242)\end{array}$ & $\begin{array}{c}0.842 \\
(0.157)\end{array}$ & $\begin{array}{c}0.829 \\
(0.202)\end{array}$ & $\begin{array}{c}0.012 \\
(0.255)\end{array}$ & $\begin{array}{c}0.575 \\
(0.169)\end{array}$ & $\begin{array}{c}0.688 \\
(0.216)\end{array}$ & $\begin{array}{r}-0.113 \\
(0.274)\end{array}$ \\
\hline 6. Line 4 - Line 5 & $\begin{array}{c}0.403 \\
(0.143)\end{array}$ & $\begin{array}{c}0.303 \\
(0.158)\end{array}$ & $\begin{array}{c}0.100 \\
(0.213)\end{array}$ & $\begin{array}{c}0.319 \\
(0.168)\end{array}$ & $\begin{array}{c}0.195 \\
(0.190)\end{array}$ & $\begin{array}{c}0.124 \\
(0.253)\end{array}$ & $\begin{array}{c}0.442 \\
(0.178)\end{array}$ & $\begin{array}{c}0.375 \\
(0.186)\end{array}$ & $\begin{array}{c}0.067 \\
(0.257)\end{array}$ \\
\hline \multicolumn{10}{|l|}{ Panel B: LOW-exposure households } \\
\hline $\begin{array}{l}\text { 7. Parental aspirations before } \\
\text { the start of PROGRESA }\end{array}$ & $\begin{array}{l}12.741 \\
(0.109)\end{array}$ & $\begin{array}{l}12.682 \\
(0.127)\end{array}$ & $\begin{array}{c}0.058 \\
(0.167)\end{array}$ & $\begin{array}{l}12.389 \\
(0.108)\end{array}$ & $\begin{array}{l}12.373 \\
(0.129)\end{array}$ & $\begin{array}{c}0.015 \\
(0.168)\end{array}$ & $\begin{array}{l}12.550 \\
(0.113)\end{array}$ & $\begin{array}{l}12.497 \\
(0.131)\end{array}$ & $\begin{array}{c}0.053 \\
(0.173)\end{array}$ \\
\hline $\begin{array}{l}\text { 8. Parental aspirations after } 6 \text { months of } \\
\text { the start of PROGRESA }\end{array}$ & $\begin{array}{l}13.712 \\
(0.082)\end{array}$ & $\begin{array}{l}13.495 \\
(0.099)\end{array}$ & $\begin{array}{c}0.217 \\
(0.128)\end{array}$ & $\begin{array}{l}13.672 \\
(0.090)\end{array}$ & $\begin{array}{l}13.425 \\
(0.130)\end{array}$ & $\begin{array}{c}0.247 \\
(0.158)\end{array}$ & $\begin{array}{l}13.633 \\
(0.088)\end{array}$ & $\begin{array}{l}13.461 \\
(0.115)\end{array}$ & $\begin{array}{c}0.172 \\
(0.145)\end{array}$ \\
\hline $\begin{array}{l}\text { 9. Parental aspirations after } 1 \text { year of } \\
\text { the start of PROGRESA }\end{array}$ & $\begin{array}{l}13.195 \\
(0.085)\end{array}$ & $\begin{array}{l}13.222 \\
(0.108)\end{array}$ & $\begin{array}{l}-0.027 \\
(0.138)\end{array}$ & $\begin{array}{l}13.098 \\
(0.094)\end{array}$ & $\begin{array}{l}13.286 \\
(0.119)\end{array}$ & $\begin{array}{l}-0.189 \\
(0.152)\end{array}$ & $\begin{array}{l}13.165 \\
(0.098)\end{array}$ & $\begin{array}{l}13.061 \\
(0.127)\end{array}$ & $\begin{array}{c}0.104 \\
(0.160)\end{array}$ \\
\hline $\begin{array}{l}\text { 10. Change in mean aspirations } \\
\text { baseline vs. } 6 \text { months }\end{array}$ & $\begin{array}{c}0.971 \\
(0.117)\end{array}$ & $\begin{array}{c}0.813 \\
(0.151)\end{array}$ & $\begin{array}{l}0.158 \\
(0.19)\end{array}$ & $\begin{array}{c}1.284 \\
(0.129)\end{array}$ & $\begin{array}{c}1.052 \\
(0.173)\end{array}$ & $\begin{array}{c}0.232 \\
(0.215)\end{array}$ & $\begin{array}{c}1.083 \\
(0.122)\end{array}$ & $\begin{array}{c}0.964 \\
(0.161)\end{array}$ & $\begin{array}{r}0.119 \\
(0.202)\end{array}$ \\
\hline $\begin{array}{l}\text { 11. Change in mean aspirations } \\
\text { baseline vs. } 1 \text { year }\end{array}$ & $\begin{array}{c}0.454 \\
(0.118)\end{array}$ & $\begin{array}{c}0.540 \\
(0.153)\end{array}$ & $\begin{array}{l}-0.085 \\
(0.193)\end{array}$ & $\begin{array}{c}0.709 \\
(0.126)\end{array}$ & $\begin{array}{c}0.913 \\
(0.168)\end{array}$ & $\begin{array}{l}-0.204 \\
(0.210)\end{array}$ & $\begin{array}{c}0.615 \\
(0.130)\end{array}$ & $\begin{array}{c}0.564 \\
(0.167)\end{array}$ & $\begin{array}{c}0.051 \\
(0.211)\end{array}$ \\
\hline 12. Line 10 - Line 11 & $\begin{array}{c}0.517 \\
(0.105)\end{array}$ & $\begin{array}{l}0.273 \\
(0.13)\end{array}$ & $\begin{array}{c}0.243 \\
(0.166)\end{array}$ & $\begin{array}{c}0.575 \\
(0.124)\end{array}$ & $\begin{array}{c}0.139 \\
(0.158)\end{array}$ & $\begin{array}{c}0.436 \\
(0.200)\end{array}$ & $\begin{array}{l}0.468 \\
(0.119)\end{array}$ & $\begin{array}{l}0.400 \\
(0.150)\end{array}$ & $\begin{array}{c}0.068 \\
(0.191)\end{array}$ \\
\hline \multicolumn{10}{|l|}{ Panel C: Triple difference estimates } \\
\hline $\begin{array}{l}\text { 13. Difference between HIGH- and LOW- } \\
\text { exposure HHs, baseline vs. } 6 \text { months }\end{array}$ & $\begin{array}{l}-0.080 \\
(0.163)\end{array}$ & $\begin{array}{c}0.077 \\
(0.177)\end{array}$ & $\begin{array}{l}-0.157 \\
(0.24)\end{array}$ & $\begin{array}{l}-0.123 \\
(0.192)\end{array}$ & $\begin{array}{l}-0.028 \\
(0.193)\end{array}$ & $\begin{array}{l}-0.095 \\
(0.272)\end{array}$ & $\begin{array}{l}-0.066 \\
(0.172)\end{array}$ & $\begin{array}{c}0.099 \\
(0.224)\end{array}$ & $\begin{array}{l}-0.165 \\
(0.282)\end{array}$ \\
\hline $\begin{array}{l}\text { 14. Difference between HIGH- and LOW- } \\
\text { exposure HHs, baseline vs. } 1 \text { year }\end{array}$ & $\begin{array}{c}0.033 \\
(0.158)\end{array}$ & $\begin{array}{l}0.047 \\
(0.18)\end{array}$ & $\begin{array}{l}-0.014 \\
(0.239)\end{array}$ & $\begin{array}{c}0.133 \\
(0.182)\end{array}$ & $\begin{array}{l}-0.084 \\
(0.211)\end{array}$ & $\begin{array}{c}0.216 \\
(0.279)\end{array}$ & $\begin{array}{l}-0.040 \\
(0.179)\end{array}$ & $\begin{array}{c}0.124 \\
(0.204)\end{array}$ & $\begin{array}{l}-0.164 \\
(0.271)\end{array}$ \\
\hline 15. Line 13 - Line 14 & $\begin{array}{l}-0.113 \\
(0.172)\end{array}$ & $\begin{array}{c}0.030 \\
(0.165)\end{array}$ & $\begin{array}{l}-0.143 \\
(0.238)\end{array}$ & $\begin{array}{l}-0.256 \\
(0.210)\end{array}$ & $\begin{array}{c}0.056 \\
(0.215)\end{array}$ & $\begin{array}{c}-0.311 \\
(0.300)\end{array}$ & $\begin{array}{c}-0.026 \\
(0.195)\end{array}$ & $\begin{array}{c}-0.025 \\
(0.207)\end{array}$ & $\begin{array}{c}-0.001 \\
(0.284)\end{array}$ \\
\hline
\end{tabular}

Note: Robust standard errors clustered at the village level in parenthesis. 
Table 12: Average Aspirations per Household Before and 6 Months After the Start of PROGRESA by Type of Household

\begin{tabular}{|c|c|c|c|c|c|c|c|c|c|}
\hline & \multicolumn{3}{|c|}{ All children } & \multicolumn{3}{|c|}{ Daughters } & \multicolumn{3}{|c|}{ Sons } \\
\hline & $\begin{array}{l}\text { Treatment } \\
\text { (i) }\end{array}$ & $\begin{array}{l}\text { Control } \\
\text { (ii) }\end{array}$ & $\begin{array}{l}\mathrm{T}-\mathrm{C} \\
\text { (iii) }\end{array}$ & $\begin{array}{l}\text { Treatment } \\
\text { (iv) }\end{array}$ & $\begin{array}{l}\text { Control } \\
\text { (v) }\end{array}$ & $\begin{array}{l}\mathrm{T}-\mathrm{C} \\
\text { (vi) }\end{array}$ & $\begin{array}{l}\text { Treatment } \\
\text { (vii) }\end{array}$ & $\begin{array}{l}\text { Control } \\
\text { (viii) }\end{array}$ & $\begin{array}{l}\mathrm{T}-\mathrm{C} \\
\text { (ix) }\end{array}$ \\
\hline \multicolumn{10}{|c|}{ Panel A: Respondent is the mother (HIGH-exposure) } \\
\hline $\begin{array}{l}\text { 1. Parental aspirations before } \\
\text { the start of PROGRESA }\end{array}$ & $\begin{array}{r}11.768 \\
(0.121)\end{array}$ & $\begin{array}{l}11.909 \\
(0.125)\end{array}$ & $\begin{array}{l}-0.140 \\
(0.173)\end{array}$ & $\begin{array}{l}11.414 \\
(0.118)\end{array}$ & $\begin{array}{l}11.621 \\
(0.120)\end{array}$ & $\begin{array}{l}-0.207 \\
(0.168)\end{array}$ & $\begin{array}{l}11.645 \\
(0.121)\end{array}$ & $\begin{array}{l}11.788 \\
(0.124)\end{array}$ & $\begin{array}{l}-0.143 \\
(0.174)\end{array}$ \\
\hline $\begin{array}{l}\text { 2. Parental aspirations after } 6 \text { months of } \\
\text { the start of PROGRESA }\end{array}$ & $\begin{array}{l}13.123 \\
(0.087)\end{array}$ & $\begin{array}{l}12.784 \\
(0.124)\end{array}$ & $\begin{array}{c}0.339 \\
(0.151)\end{array}$ & $\begin{array}{l}13.011 \\
(0.095)\end{array}$ & $\begin{array}{l}12.693 \\
(0.134)\end{array}$ & $\begin{array}{c}0.318 \\
(0.164)\end{array}$ & $\begin{array}{l}13.079 \\
(0.090)\end{array}$ & $\begin{array}{l}12.784 \\
(0.121)\end{array}$ & $\begin{array}{c}0.295 \\
(0.151)\end{array}$ \\
\hline $\begin{array}{l}\text { 3. Change in mean aspirations } \\
\text { baseline vs. } 6 \text { months }\end{array}$ & $\begin{array}{c}1.355 \\
(0.121)\end{array}$ & $\begin{array}{c}0.875 \\
(0.159)\end{array}$ & $\begin{array}{c}0.480 \\
(0.200)\end{array}$ & $\begin{array}{c}1.597 \\
(0.128)\end{array}$ & $\begin{array}{c}1.072 \\
(0.168)\end{array}$ & $\begin{array}{c}0.525 \\
(0.211)\end{array}$ & $\begin{array}{c}1.434 \\
(0.130)\end{array}$ & $\begin{array}{c}0.996 \\
(0.161)\end{array}$ & $\begin{array}{c}0.438 \\
(0.207)\end{array}$ \\
\hline \multicolumn{10}{|c|}{ Panel B: Respondent is NOT the mother (LOW-exposure) } \\
\hline $\begin{array}{l}\text { 4. Parental aspirations before } \\
\text { the start of PROGRESA }\end{array}$ & $\begin{array}{r}11.710 \\
(0.175)\end{array}$ & $\begin{array}{l}11.484 \\
(0.259)\end{array}$ & $\begin{array}{c}0.226 \\
(0.313)\end{array}$ & $\begin{array}{l}11.415 \\
(0.176)\end{array}$ & $\begin{array}{l}11.142 \\
(0.237)\end{array}$ & $\begin{array}{c}0.274 \\
(0.295)\end{array}$ & $\begin{array}{l}11.639 \\
(0.175)\end{array}$ & $\begin{array}{l}11.428 \\
(0.256)\end{array}$ & $\begin{array}{c}0.210 \\
(0.310)\end{array}$ \\
\hline $\begin{array}{l}\text { 5. Parental aspirations after } 6 \text { months of } \\
\text { the start of PROGRESA }\end{array}$ & $\begin{array}{l}13.234 \\
(0.173)\end{array}$ & $\begin{array}{l}13.077 \\
(0.184)\end{array}$ & $\begin{array}{c}0.158 \\
(0.253)\end{array}$ & $\begin{array}{l}13.100 \\
(0.203)\end{array}$ & $\begin{array}{l}12.842 \\
(0.178)\end{array}$ & $\begin{array}{c}0.258 \\
(0.270)\end{array}$ & $\begin{array}{l}13.255 \\
(0.193)\end{array}$ & $\begin{array}{l}13.241 \\
(0.200)\end{array}$ & $\begin{array}{c}0.014 \\
(0.277)\end{array}$ \\
\hline $\begin{array}{l}\text { 6. Change in mean aspirations } \\
\text { baseline vs. } 6 \text { months }\end{array}$ & $\begin{array}{l}1.524 \\
(0.217)\end{array}$ & $\begin{array}{l}1.593 \\
(0.304)\end{array}$ & $\begin{array}{l}-0.068 \\
(0.373)\end{array}$ & $\begin{array}{l}1.685 \\
(0.234)\end{array}$ & $\begin{array}{c}1.700 \\
(0.283)\end{array}$ & $\begin{array}{l}-0.016 \\
(0.366)\end{array}$ & $\begin{array}{l}1.616 \\
(0.227)\end{array}$ & $\begin{array}{l}1.813 \\
(0.315)\end{array}$ & $\begin{array}{l}-0.196 \\
(0.388)\end{array}$ \\
\hline Panel C: Triple difference estimates & & & & & & & & & \\
\hline $\begin{array}{l}\text { 7. Difference between HIGH- and LOW- } \\
\text { exposure HHs, baseline vs. } 6 \text { months }\end{array}$ & $\begin{array}{l}-0.169 \\
(0.223)\end{array}$ & $\begin{array}{l}-0.717 \\
(0.316)\end{array}$ & $\begin{array}{c}0.548 \\
(0.386)\end{array}$ & $\begin{array}{l}-0.087 \\
(0.247)\end{array}$ & $\begin{array}{l}-0.628 \\
(0.302)\end{array}$ & $\begin{array}{c}0.541 \\
(0.390)\end{array}$ & $\begin{array}{l}-0.182 \\
(0.230)\end{array}$ & $\begin{array}{l}-0.816 \\
(0.328)\end{array}$ & $\begin{array}{c}0.634 \\
(0.401)\end{array}$ \\
\hline
\end{tabular}

Note: Robust standard errors clustered at the village level in parenthesis.

Table 13: Average Aspirations per Household Before and 1 Year After the Start of PROGRESA by Type of Household

\begin{tabular}{|c|c|c|c|c|c|c|c|c|c|}
\hline & \multicolumn{3}{|c|}{ All children } & \multicolumn{3}{|c|}{ Daughters } & \multicolumn{3}{|c|}{ Sons } \\
\hline & $\begin{array}{l}\text { Treatment } \\
\text { (i) }\end{array}$ & $\begin{array}{l}\text { Control } \\
\text { (ii) }\end{array}$ & $\begin{array}{l}\mathrm{T}-\mathrm{C} \\
\text { (iii) }\end{array}$ & $\begin{array}{l}\text { Treatment } \\
\text { (iv) }\end{array}$ & $\begin{array}{l}\text { Control } \\
\text { (v) }\end{array}$ & $\begin{array}{l}\mathrm{T}-\mathrm{C} \\
\text { (vi) }\end{array}$ & $\begin{array}{l}\text { Treatment } \\
\text { (vii) }\end{array}$ & $\begin{array}{l}\text { Control } \\
\text { (viii) }\end{array}$ & $\begin{array}{l}\mathrm{T}-\mathrm{C} \\
\text { (ix) }\end{array}$ \\
\hline \multicolumn{10}{|c|}{ Panel A: Respondent is the mother (HIGH-exposure) } \\
\hline $\begin{array}{l}\text { 1. Parental aspirations before } \\
\text { the start of PROGRESA }\end{array}$ & $\begin{array}{c}11.791 \\
(0.124)\end{array}$ & $\begin{array}{l}11.899 \\
(0.135)\end{array}$ & $\begin{array}{l}-0.108 \\
(0.183)\end{array}$ & $\begin{array}{l}11.424 \\
(0.120)\end{array}$ & $\begin{array}{l}11.628 \\
(0.131)\end{array}$ & $\begin{array}{l}-0.205 \\
(0.178)\end{array}$ & $\begin{array}{l}11.663 \\
(0.124)\end{array}$ & $\begin{array}{l}11.779 \\
(0.134)\end{array}$ & $\begin{array}{l}-0.116 \\
(0.182)\end{array}$ \\
\hline $\begin{array}{l}\text { 2. Parental aspirations after } 1 \text { year of } \\
\text { the start of PROGRESA }\end{array}$ & $\begin{array}{l}12.684 \\
(0.085)\end{array}$ & $\begin{array}{l}12.580 \\
(0.116)\end{array}$ & $\begin{array}{c}0.104 \\
(0.144)\end{array}$ & $\begin{array}{l}12.683 \\
(0.092)\end{array}$ & $\begin{array}{l}12.499 \\
(0.128)\end{array}$ & $\begin{array}{c}0.183 \\
(0.158)\end{array}$ & $\begin{array}{l}12.587 \\
(0.090)\end{array}$ & $\begin{array}{l}12.527 \\
(0.123)\end{array}$ & $\begin{array}{c}0.060 \\
(0.152)\end{array}$ \\
\hline $\begin{array}{l}\text { 3. Change in mean aspirations } \\
\text { baseline vs. } 1 \text { year }\end{array}$ & $\begin{array}{c}0.892 \\
(0.124)\end{array}$ & $\begin{array}{c}0.681 \\
(0.181)\end{array}$ & $\begin{array}{c}0.211 \\
(0.219)\end{array}$ & $\begin{array}{l}1.259 \\
(0.120)\end{array}$ & $\begin{array}{c}0.871 \\
(0.186)\end{array}$ & $\begin{array}{c}0.388 \\
(0.229)\end{array}$ & $\begin{array}{c}0.924 \\
(0.125)\end{array}$ & $\begin{array}{c}0.748 \\
(0.185)\end{array}$ & $\begin{array}{c}0.176 \\
(0.223)\end{array}$ \\
\hline \multicolumn{10}{|c|}{ Panel B: Respondent is NOT the mother (LOW-exposure) } \\
\hline $\begin{array}{l}\text { 4. Parental aspirations before } \\
\text { the start of PROGRESA }\end{array}$ & $\begin{array}{r}11.605 \\
(0.262)\end{array}$ & $\begin{array}{l}11.227 \\
(0.329)\end{array}$ & $\begin{array}{c}0.378 \\
(0.420)\end{array}$ & $\begin{array}{r}11.418 \\
(0.262)\end{array}$ & $\begin{array}{l}10.766 \\
(0.335)\end{array}$ & $\begin{array}{c}0.652 \\
(0.426)\end{array}$ & $\begin{array}{l}11.483 \\
(0.264)\end{array}$ & $\begin{array}{l}11.207 \\
(0.328)\end{array}$ & $\begin{array}{c}0.276 \\
(0.422)\end{array}$ \\
\hline $\begin{array}{l}\text { 5. Parental aspirations after } 1 \text { year of } \\
\text { the start of PROGRESA }\end{array}$ & $\begin{array}{l}12.598 \\
(0.273)\end{array}$ & $\begin{array}{l}12.426 \\
(0.342)\end{array}$ & $\begin{array}{c}0.173 \\
(0.438)\end{array}$ & $\begin{array}{l}12.543 \\
(0.324)\end{array}$ & $\begin{array}{l}12.280 \\
(0.362)\end{array}$ & $\begin{array}{c}0.263 \\
(0.486)\end{array}$ & $\begin{array}{l}12.753 \\
(0.297)\end{array}$ & $\begin{array}{l}12.413 \\
(0.363)\end{array}$ & $\begin{array}{c}0.340 \\
(0.469)\end{array}$ \\
\hline $\begin{array}{l}\text { 6. Change in mean aspirations } \\
\text { baseline vs. } 1 \text { year }\end{array}$ & $\begin{array}{c}0.994 \\
(0.284)\end{array}$ & $\begin{array}{c}1.199 \\
(0.492)\end{array}$ & $\begin{array}{l}-0.205 \\
(0.567)\end{array}$ & $\begin{array}{l}1.125 \\
(0.336)\end{array}$ & $\begin{array}{l}1.514 \\
(0.449)\end{array}$ & $\begin{array}{l}-0.389 \\
(0.560)\end{array}$ & $\begin{array}{l}1.270 \\
(0.264)\end{array}$ & $\begin{array}{c}1.205 \\
(0.517)\end{array}$ & $\begin{array}{c}0.065 \\
(0.589)\end{array}$ \\
\hline \multicolumn{10}{|l|}{ Panel C: Triple difference estimates } \\
\hline $\begin{array}{l}\text { 7. Difference between HIGH- and LOW- } \\
\text { exposure HHs, baseline vs. } 1 \text { year }\end{array}$ & $\begin{array}{l}-0.102 \\
(0.298)\end{array}$ & $\begin{array}{l}-0.518 \\
(0.510)\end{array}$ & $\begin{array}{c}0.416 \\
(0.590)\end{array}$ & $\begin{array}{c}0.134 \\
(0.343)\end{array}$ & $\begin{array}{l}-0.643 \\
(0.474)\end{array}$ & $\begin{array}{c}0.777 \\
(0.584)\end{array}$ & $\begin{array}{l}-0.346 \\
(0.307)\end{array}$ & $\begin{array}{l}-0.457 \\
(0.531)\end{array}$ & $\begin{array}{c}0.111 \\
(0.612)\end{array}$ \\
\hline
\end{tabular}

Note: Robust standard errors clustered at the village level in parenthesis. 
Table 14: Effect of Parental Aspirations on Their Children's Time Spent Doing Homework and Working

\begin{tabular}{|c|c|c|c|c|c|c|c|c|c|}
\hline & \multicolumn{3}{|c|}{ All children } & \multicolumn{3}{|c|}{ Daughters } & \multicolumn{3}{|c|}{ Sons } \\
\hline & $(1)$ & $(2)$ & (3) & (4) & $(5)$ & $(6)$ & (7) & $(8)$ & (9) \\
\hline \multicolumn{10}{|c|}{ Panel A: Effect of Parental Aspirations on Their Children's Time Spent Doing Homework } \\
\hline Parental aspirations & $\begin{array}{c}1.284 * * \\
(0.554)\end{array}$ & $\begin{array}{c}1.372 * * \\
(0.562)\end{array}$ & $\begin{array}{c}1.368 * * \\
(0.566)\end{array}$ & $\begin{array}{c}1.039 * * * \\
(0.378)\end{array}$ & $\begin{array}{c}0.908 * * \\
(0.410)\end{array}$ & $\begin{array}{c}0.884 * * \\
(0.412)\end{array}$ & $\begin{array}{c}1.729 * * * \\
(0.431)\end{array}$ & $\begin{array}{c}1.383 * * * \\
(0.436)\end{array}$ & $\begin{array}{c}1.354 * * * \\
(0.430)\end{array}$ \\
\hline Controls for parental characteristics ${ }^{1}$ & No & Yes & Yes & No & Yes & Yes & No & Yes & Yes \\
\hline Controls for household characteristics ${ }^{2}$ & No & No & Yes & No & No & Yes & No & No & Yes \\
\hline Probability value for controls ${ }^{3}$ & --- & 0.046 & 0.003 & --- & 0.294 & 0.012 & --- & 0.029 & 0.008 \\
\hline Obs. & 2,601 & 2,350 & 2,350 & 1,237 & 1,115 & 1,115 & 1,268 & 1,151 & 1,151 \\
\hline $\mathrm{R}^{2}$ (overall) & 0.003 & 0.011 & 0.204 & 0.006 & 0.014 & 0.030 & 0.012 & 0.028 & 0.043 \\
\hline \multicolumn{10}{|c|}{ Panel B: Effect of Parental Aspirations on Their Children's Time Spent Working (at Home and Outside) } \\
\hline Parental aspirations & $\begin{array}{l}-1.267 \\
(1.061)\end{array}$ & $\begin{array}{c}-1.037 \\
(1.072)\end{array}$ & $\begin{array}{l}-1.150 \\
(1.045)\end{array}$ & $\begin{array}{c}-0.304 \\
(0.449)\end{array}$ & $\begin{array}{c}-0.164 \\
(0.460)\end{array}$ & $\begin{array}{l}-0.156 \\
(0.445)\end{array}$ & $\begin{array}{l}-0.335 \\
(0.962)\end{array}$ & $\begin{array}{l}-0.197 \\
(1.000)\end{array}$ & $\begin{array}{l}-0.297 \\
(0.990)\end{array}$ \\
\hline Controls for parental characteristics ${ }^{1}$ & No & Yes & Yes & No & Yes & Yes & No & Yes & Yes \\
\hline Controls for household characteristics ${ }^{2}$ & No & No & Yes & No & No & Yes & No & No & Yes \\
\hline Probability value for controls ${ }^{3}$ & --- & 0.000 & 0.000 & --- & 0.298 & 0.160 & --- & 0.000 & 0.000 \\
\hline Obs. & 2,601 & 2,350 & 2,350 & 1,778 & 1,607 & 1,607 & 1,850 & 1,682 & 1,682 \\
\hline $\mathrm{R}^{2}$ (overall) & 0.001 & 0.022 & 0.067 & 0.003 & 0.004 & 0.024 & 0.000 & 0.019 & 0.051 \\
\hline
\end{tabular}

Note: Robust standard errors clustered at the village level in parenthesis. Each individual coefficient is statistically significant at the $* 10 \%$, $* * 5 \%$, or $* * * 1 \%$ level.

${ }^{1}$ Head's age, his educational level, whether he is literate, whether he is indigenous, the spouse's age, her educational level, whether she is literate, and whether she is indigenous.

${ }^{2}$ The number of male and female adults, the number of male and female children, and the household's monthly income.

${ }^{3}$ Probability value of joint $F$ test for exclusion of all control variables. 